Portland State University

PDXScholar

10-31-1995

\title{
The Love Poems of John Clare and John Keats: A Comparative Study
}

\author{
Elizabeth Stafford Grodd
}

Portland State University

Follow this and additional works at: https://pdxscholar.library.pdx.edu/open_access_etds

Part of the English Language and Literature Commons Let us know how access to this document benefits you.

\section{Recommended Citation}

Grodd, Elizabeth Stafford, "The Love Poems of John Clare and John Keats: A Comparative Study" (1995). Dissertations and Theses. Paper 4907.

https://doi.org/10.15760/etd.6783

This Thesis is brought to you for free and open access. It has been accepted for inclusion in Dissertations and Theses by an authorized administrator of PDXScholar. Please contact us if we can make this document more accessible: pdxscholar@pdx.edu. 
The abstract and thesis of Elizabeth Stafford Grodd for the Master of Arts in English were presented October 31, 1995, and accepted by the thesis committee and the department.

COMMITTEE APPROVALS:

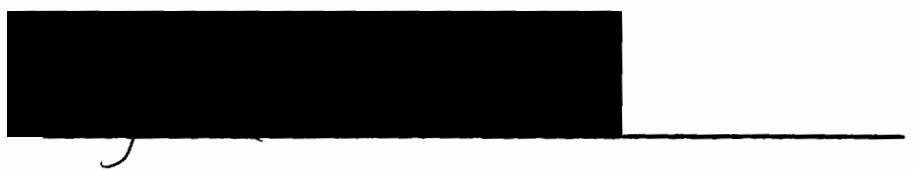
Ray Mariels, Chair

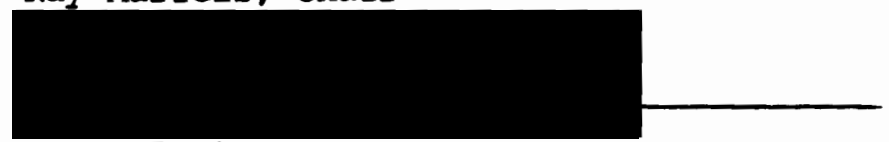

Nancy Porter

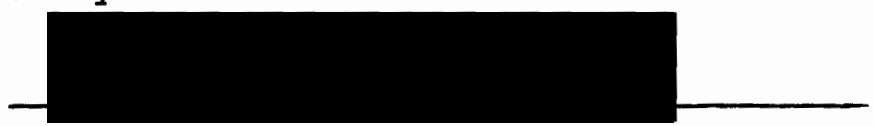

Sherrie I. Gradin

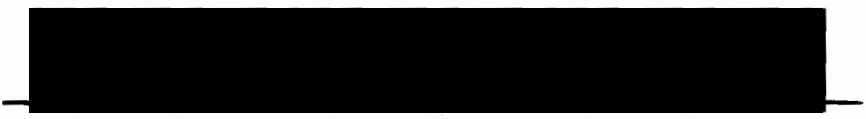

Claudine G. Fisher, Representative office of Graduate Studies

DEPARTMENT APPROVAL:

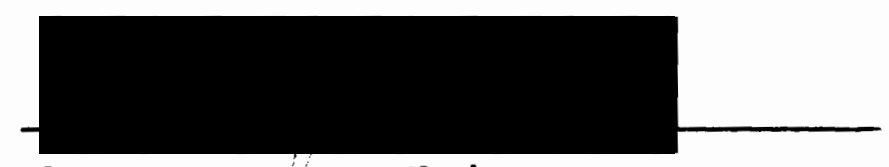

Shelley C. Reece, Chair Department of English

ACCEPTED FOR PORTLAND STATE UNIVERSITY BY THE LIBRARY

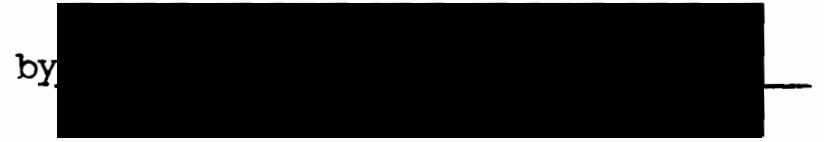

on 2 Powerex 1995 
ABSTRACT

An abstract of the thesis of Elizabeth Stafford Grodd for the Master of Arts in English presented October 31, 1995.

Title: The Love Poems of John Clare and John Keats: A Comparative Study

This study addresses lesser known works of romantic poets John Clare and John Keats--Clare's Child Harold and Keats's poems to Fanny Brawne-which I refer to as their love poems because the works are informed by intense feelings the poets had for women they loved. Although these works have been the brunt of negative criticism because Clare was considered insane at the time of the composition of Child Harold and Keats was accused of using the poems to give vent to his personal sufferings, nonetheless I argue that the love poems are significant for several reasons. They are a reflection of the poets' personal experiences and also demonstrate their remarkable and surprisingly similar creative abilities in the way they use poetry as a means of devising new strategies for dealing with the painful realities of their disturbing lives. And because $I$ feel it is important to understand Clare's and Keats's feelings for the women they love in order to understand their poetry (since the poetry is, after all, based on real life experiences), I provide chapters 
describing the poets's lives and loves, as well as their poetic processes, to serve as a framework for examining the poems. In the remaining chapters, I show how the poets incorporate highly sophisticated metaphor in attempting to reconcile the apparent conflicts the speakers in their poems are experiencing between their subjective responses to, and their rational assessment of human existence. In the process, the speakers experience various states of emotional upheaval ranging from what I refer to as periods of limbo, purgatory, and paradise, and they create personal thresholds and undergo differing states of self-awareness. In the final chapter I provide a summary of how these different emotional states are metaphorically effected, and then attempt to explain the value of Clare's and Keats's poetic achievements in the poems from a current perspective. 
THE LOVE POEMS OF JOHN CLARE AND JOHN KEATS:

A COMPARATIVE STUDY

$$
\text { by }
$$

ELIZABETH STAFFORD GRODD

A thesis submitted in partial fulfillment of the requirements for the degree of

MASTER OF ARTS

in

ENGLISH

Portland State University 1995 
TABLE OF CONTENTS

ACKNOWLEDGEMENTS • • • . • . . . . . . . . . . . . . • . ii INTRODUCTION. • . . . . . . . . . . . . . . . . . . . 1 THE POETS: THEIR LIVES AND LOVES. . . . . . . . . . . . . . . I1 JOHN CLARE'S POETIC PROCESS. • . . . . . . . . . . . . . . 27 JOHN KEATS'S POETIC PROCESS. . . . . . . . . . . . . . . . 43 LTMBO. . . . . . . . . . . . . . . . . . . . . . . . . PURGATORY. • . • . . . . . . . . . . . . . . . . . 70 PARADISE. . . . . . . . . . . . . . . . . . . 88 THE LOVE POEMS OF JOHN CLARE AND JOHN KEATS: THE

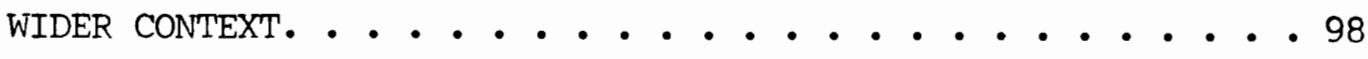
SELECTED BIBLIOGRAPHY. • • • • • • • • • • • • • • 108 


\section{ACKNOWLEDGEMENTS}

It has been an extreme pleasure working with such a fine thesis committee. I would like to thank Ray Mariels, my thesis advisor, for inspiring me to begin this work and for his most valuable guidance along the way. I am also grateful to my "editors," Nancy Porter and Sherrie Gradin, for their expert advice. Gratitude is also extended to Claudine Fisher for her faith and encouragement, and to my friend and colleague, Mary Smith, for her careful reading and helpful suggestions.

This work is dedicated to my husband, Laurence, without whose many levels of support my graduate studies would have been impossible. 
CHAPTER I

INTRODUCTION

My interest in the similarities between poets John Clare and John Keats was inspired in part by John Purkis's The World of the English Romantic Poets: A Visual Approach. Though I had long been aware of Keats's excellence as a poet, I had no knowledge of John Clare until I read Purkis's brief discussion of him in relation to keats in a chapter entitled "The Poetry of the Earth." Purkis notes that in "To Autumn" Keats "presents the harvest of a life spent in observing nature," and "a rich haze of memories hangs about the poem" (116). However, since Keats never experienced the life of a real farm laborer while Clare did, Purkis likens Clare's appearance on the literary scene, "offering himself for serious consideration as a poet," to Samuel Palmer's picture The Sleeping Shepherd, as if Clare were the figure in the picture and actually stood up and spoke. What we have in Clare's work, he claims, "is a humility before Nature which makes much of the work of other - . poets seem patronizing" because they are "always trying to use Nature, to make it fit a theory about the Universe (Wordsworth)," or "to illustrate a mood or symbolize a feeling (Byron, much of Shelley and Keats)." Whereas, Clare reports and describes "what is there to be seen, assuming that this in itself is a valuable activity" (124). 
As I read more of Clare's poetry, what particularly intrigued me, besides Clare's ability as a descriptive nature poet as Purkis noted, was how his intense feelings for his long-lost first love, Mary Joyce, informed so much of his poetry. During the same period I became interested in Keats's love poems to Fanny Brawne, through the helpful suggestion of one of my professors who claimed that these poems had long been overlooked by critics and deserved further study. Though I began noting resemblances in feeling and intensity in their poems, it was only after many months of research that I succeeded in finding strong links, which resulted in this thesis, (The Love Poems of John Clare and John Keats: A Comparative Study), in which I explore the approaches the poets take in their perception of nature and the connections they make between their feelings and the women they love. My primary focus is on the poets' more obscure works--selected stanzas and songs from Clare's epic length poem Child Harold and Keats's "What do I do to drive away the pain," "To Fanny," and "You Say You Love." But I also include some of Keats's more familiar poems such as "Bright Star" and "To Autumn," which are comparable to Clare's poem in mood, thought, and symbolism.

Though it is not immediately obvious, many parallels can be drawn between Clare's and Keats's lives. Both began their careers during the early part of the 19th century. Though never formally introduced, they shared the same publisher, John Taylor, who recognized them as poetic geniuses. Neither of them fit easily into the mainstream of the Iondon literary scene; neither had the advantages of higher education, yet both read widely and deeply through their own efforts. 
Each career was hampered by financial instability, deteriorating health, and star-crossed love affairs. In addition, their poetry received mixed and often bitter critical reviews. Though Keats eventually received the wide recognition he deserved, clare did not and is still considered a minor poet.

With regard to publishers and critics, Keats had the advantage over Clare because he was a Londoner by birth and manners; while Clare, a peasant and day laborer of the north country, did not immediately appeal to London tastes and posed considerable problems for his patrons and editors who decided to market him as a "peasant poet." Although Keats was fortunate in having the opportunity to select the poems he wished to offer for publication, clare suffered from what one of his critics terms as the "heavy-handed editing" of his publishers, who tried to revise and condense his works. There were occasions when Clare's editors altered his lines, his punctuation and his language so he would come across as a tame "peasant poet;" at other times he would comply with their wishes and produce trivial drawing-room ballads and pieces of nature observation similar to those that abounded in the literary journals of Regency and Victorian England. Literary historian John Lucas concludes that as a result of Clare's editors' marketing strategy, clare felt he was forced to adopt a voice which denied him his sense of community and self.

Unfortunately, this silencing of Clare continues to be a problem today. If he is included at all in the most recent anthologies, the poems selected are usually those written early in his career, while 
those he wrote in maturity, such as Child Harold, are dismissed because they were composed when clare was considered insane. In the introduction to Selected Poems and Prose of John Clare (1967), widely respected editors Eric Robinson and Geoffrey Summerfield acknowledge that there is no question that clare in his later years developed a very distinctive voice, an unmistakable intensity and vibrance, such as the later pictures of Van Gogh possess, yet they discount the value of the poems, insisting that "we must also guard against attributing too much importance to the poems of his madness because we live in an age fascinated by the problems of mental stress" (xxxii).

Keats's love poems to Fanny Brawne have been the brunt of unwarranted negative criticism and almost total rejection by some of the most noteworthy authorities on his work. Although they were written during Keats's annus mirabilis, shortly after "The Eve of St. Agnes" and the great odes, Paul de Man notes that many critics consider the poems "poetically unimportant and slightly embarrassing documents written when Keats was no longer in full control of his faculties" (xxvi); Douglas Bush, in his respected biography John Keats, contends that the poems count as "feverish, painful outcries" rather than poetry (180); and in A Preface to Keats, Cedric Watts refers to one of the poems as "inferior" and "overtly biographical" (Watts 154). It seems that critics have problems accepting the love poems and find them disconcerting because they clearly reflect the emotional trauma Keats was experiencing at the time. As deMan points out, unlike his major works where the definitive "I" of Keats's own selfhood is usually hidden in objectivity, the subject of the poems to 
Fanny Brawne is not an impersonal entitiy like the urn or the nightingale, but a distinct and viable person who awakens in him feelings of apprehension and jealousy; and Gittings argues that "the special imagery in the poems suggests a dilemma peculiar to Keats himself" (359). By giving vent to his own sufferings in the love poems, perhaps critics felt Keats destroyed the image he had created of the poet as the "redeemer" of mankind's sufferings.

Clare and Keats wrote their love poems when racked by disease and torn by the love they were denied. The ideas they express and the aesthetic standards they set for beauty were based on intense feelings for their first loves. As John Middleton Murry in "Keats and Shakespeare" points out, "those who cannot understand Keats's love will never understand his poetry, for these two things spring from a single source" (214). The same is true of John Clare. Their love poems are significant because they are a reflection of their disturbing lives and show their remarkable and surprisingly similar creative abilities in the way they use their poetry as a means of devising new strategies for dealing with their painful realities. In order to elucidate these important issues, Chapter II provides background on the poets' lives and loves, and Chapters III and IV describe Clare's and Keats's poetic processes. Chapters V, VI, and VII are devoted to an in-depth study and comparison of the poems themselves, demonstrating how Clare and Keats use their poetry in trying to reconcile the apparent conflicts the personas of the poems are experiencing between their subjective responses to, and their rational assessment of human existence, especially with regard to 
their lives as poets and lovers. In particular, I will show how the poets use highly sophisticated metaphor in attempting to project the self into the essence of love and to realize love in earthly terms, yet cleansed of the inevitable pain that comes from being mortal. In the process, the speakers experience various states of emotional upheaval ranging from what I describe as periods of emotional Limbo in Chapter V, to Purgatory in Chapter VI, and Paradise in Chapter VII, and they create personal thresholds and undergo differing states of self-awareness. In the final chapter, "The Love Poems of Clare and Keats: The wider Context," I provide an elaborated summary of how these different emotional states are metaphorically effected, and then attempt to explain the value of the poetic achievement in the poems from a current perspective. Specifically, how famine, war, racism, and other unnecessary tragedies might be averted if we were to emulate these poets' persistent belief in the healing power of love. Viewed in this light, hopefully this study will prompt readers to recognize, or at least to to reassess these long neglected works.

\section{Textual Note}

There is no edition of Clare's poetry that is both complete and reliable because much of what clare wrote has been corrupted by careless or misguided editing, beginning with his first publisher in 1820 and continuing, with a few exceptions, to the present. Clare was probably the most prolific of all English poets, composing about two-thousand poems during his lifetime; but as Eric Robinson points out, the editorial effort involved in making an edition of clare's 
work is phenomenal because Clare was also the untidiest. He remarks that "the sheer bulk of material, the intricacies of much of the handwriting, the state of the manuscripts which are often mere scraps of paper pasted into a larger book, the apparent disorder of clare's creative processes which produced notes, poems, letters, and anagrams all mixed together in a furious welter" create immense difficulties that every editor of Clare must encounter ( Unfortunately, because of the inconsistency and indescretion of editorial decisions resulting from the disarray of clare's manuscripts, some of which may still be lurking in someone's attic in the United States or England, readers of Clare are confronted with a maze of "authoritative" texts which differ dramatically. In the case of Child Harold this is especially true.

The most original of his long poems, Child Harold (which consists of about forty pages of poetry, interspersed with songs and ballads), did not appear in print until J. W. Tibble's The Poems of John Clare (1935), seventy-five years after his death. At that time, the material was arranged into a series of separate poems and songs without acknowledging Clare's original intent of a large, single work. The 1950 version edited by Geoffry Grigson was severely cut, with the interspersed songs and ballads completely eliminated, and with a dubious arrangement of the poetry. As a result of its erratic editorial history, Child Harold's critical reception has been recent and brief, marked by the inevitable confusion of any commentary which is based on unreliable texts. For example, in an important critical study of the poem in The Poetry of John Clare, which was based on 
Grigson's mutilated version, Mark Storey sums up Child Harold as "a hybrid poem of near-madness.....a pathetic poem, one to which it is particularly difficult (and perhaps inapposite) to apply the usual critical responses," and concludes that, "as a whole the poem lacks structure and polish" (Howard 154). Not until 1964, in Eric Robinson and Geoffry Summerfield's The Later Poems of John Clare, was the poem published in a form that respected the arrangement of the poetry, songs, and ballads in Clare's notebooks.

With regard to the imitative features of Clare's Child Harold with Byron's original poem by the same name, it has long been recognized that one distinctive symptom of Clare's insanity was his intermittent delusion that he was other people such as the boxers Ben Caunt, Jack Randall and Tome Spring, as well as Lord Nelson, the Duke of Wellington, Robert Burns, and Shakespeare. In terms of his poetry, the most important of his confusions was his belief that he was Lord Byron, and what attracted Clare to Byron as a man was his "liberal principles in religion \& politics" and his "undisguisd honesty" (Chilcott 147). Though Clare's identification with Byron was intense during the asylum years, and Clare closely imitates the style and structure of his Byronic model, Tim Chilcott asserts that other features of the poem suggest that clare was striking out in new directions, and that there is a clear sense in which Child Harold (as well as Don Juan) represent innovation rather than mere imitation of earlier poems, whether by Byron or by Clare himself. He contends that the perceptions in Child Harold are obviously the product of Clare's personal inquiry and quest (158). 
In 1984, Eric Robinson remarked that the value of Clare's poetry as a whole had been established for the majority of English readers, but Clare remains unknown to most of the American reading public, and primary and secondary sources on his work are extremely sparse. This study is indebted to Portland State Library for Eric Robinson and David Powell's two volume editions of The Later Poems of John Clare, 1837-1864 (1984) and The Early Poems of John Clare (1989) which will serve as primary references for Clare's poetry. Quotations from Clare's letters are from various sources which are referenced in the Bibliography .

The primary source for Keats's poetry and letters is The Oxford Authors' 1990 edition of John Keats, edited by Elizabeth Cook. In contrast with Clare, Keats's poetry did not present many editorial problems because, of the 150 or so poems in the Keats canon, around fifty-four of the poems were seen through the press by Keats himself. The Oxford Authors' edition presents the latest published form in which Keats saw the poems, with the exception of "Ia belle dame sans merci," which is Keats's draft of the poem rather than the version printed in the Indicator, and is the better known form. However, because Keats's poems to Fanny Brawne are more personal in subject matter than his other works, it is unclear whether he intended them for publication; but, like his love letters, they eventually made their way through the press. Hopefully, the choice of primary sources for both clare and Keats will insure, for the most part, that my study of the poetry will be based on versions most closely reflecting the authors' original works. 
Selection of secondary sources for both authors presented a challenge because so very little critical attention has been given to Clare's Child Harold, and critical discussions of Keats's poems to Fanny Brawne are virtually non-existent. Moreover, no one has ever attempted an in-depth comparison of their work. Therefore, in examining how patterns and meanings operate in the context of Clare's and Keats's poems, this study relies heavily on the techniques Earl Wasserman employs in his explication of Keat's major works in The Finer Tone and on William Howard's critical interpretation of Claire's poetry in John Clare.

With regard to biographical sources, accounts of Keats's biography are fairly consistent and did not present any problems, but I discovered that differing accounts of Clare's life paint contradictory pictures of the man and poet. At one extreme he is portrayed as "the archetypal genius, inspired untutored poet, and raving lunatic all rolled conveniently into one" (Storey 2 ); at the other extreme he is depicted like Hilton's generic portrait of him (similar to those of Keats, Shelley, Byron, etc.), the way the 19th century Romantics would have liked him to have been: "handsome, curly-haired, and beautifully wholesome in the carefully arranged disorder of his clothes" (Robinson SPPJC xxviii). So I have chosen to rely on William Howard's biographical assessment of Clare in John Clare because his study seems the most thorough and moderate approach. 
CHAPTER II

THE POETS: THEIR LIVES AND LOVES

\section{John Clare}

John Clare was born into poverty in the Northamptonshire village of Helpston on July 13, 1793. The bare outlines of his tragic life prove that he learned, probably better than most of his contemporaries, the truth of William Wordsworth's lines: "We poets in our youth begin in gladness; / But thereof comes in the end despondency and madness" (Howard 70). Clare's life and his work were "centered on the confusions wrought by change" which took various forms: the enclosure of his native village, unexpected fame, neglect, reluctant marriage, the loss of his childhood love, relocation, and confinement. Much of his poetry is "a searching into the corners of memory, an attempt to create out of his losses a permanence denied him in the present" (Storey, PJC 9).

Because his family relied on him for subsistence, Clare was forced to leave school at the age of twelve, and worked at a variety of jobs including thresher, ploughboy and limeburner; but he attended night school at nearby Glinton where he met his first love Mary Joyce, who immediately won his heart's affections and would inform his ideas of love and beauty for the rest of his life. 
Clare's parents were dedicated to their children. His mother recognized his continual appetite for learning and encouraged his scholarly pursuits which consisted of informal study with other children in Helpston. His father introduced him to the many ballads and songs which the family had handed down for generations, which were to form the basis of much of his literary development. Though he had several childhood friends, Clare was sometimes lonely, but found the solitary tending of sheep and cows, hunting for birds' nests, and fishing a source of pleasure. Despite the family's hardships, Clare's early years were essentially happy and carefree, and poems recollecting these times "consistently stress the contrast between the joys of early life and the torment of his adult years" (Howard 14).

Clare began writing poetry for his own amusement when he was quite young, after reading James Thomson's Seasons in a copy loaned to him by one of his friends. By the time he was twenty-five, he was seriously contemplating the publication of some of his poems. Spotted by Edward Drury, a local bookseller and cousin to the publisher John Taylor whose store clare often frequented, he received encouragement and financial support, and Taylor decided to become his publisher. Clare's first volume, Poems Descriptive of Rural Life and Scenery, published in 1820, was an overnight success. He was fêted by Iondon literary circles, and wined and dined by Taylor who marketed him as the "Northamptinshire Peasant Poet." It was during this same year that Clare married Martha "Patty" Turner, who was pregnant with his child, which was to be the first of seven Patty would bear during their marriage. Though Clare married Patty reluctantly, never managing to 
forget his first love, Mary Joyce, his regard for her grew with each passing year and he began to value and depend upon Patty's ability to care for the needs of his rapidly expanding family and to nurse him through his own illnesses.

Though Clare was pleased with the immediate success of his first volume of poetry, the fame that followed disconcerted him because the succession of visitors, many of whom were condescending, patronizing, or simply rude, disrupted the quiet home life he valued. But clare's popularity was short-lived. With his second and subsequent collections of poetry, public acclaim faded into neglect and the period between 1820 and 1828 was marked by "fits of prolific composition interspersed with sometimes lengthy stretches of inactivity caused either by illness or disillusionment" and by "intense conflict between his private and poetic lives" (Howard 20). On the one hand, he had always been sincere about his vocation as a poet and enjoyed and needed the stimulus that his London literary friends provided; while on the other, he was beginning to realize that poetry would never support his growing family and provide the financial independence he sought.

In 1832 he moved from this native village of Helpston to Northborough with hopes of a better livelihood, but for Clare, the move set off a personal emotional crisis. He realized that leaving his familiar surroundings also meant giving up the sole source and inspiration for his poetry which his beloved landscape represented for him, particularly fond memories of his youth and first love, Mary Joyce, thus severing all links to the past. Though enclosure had 
already changed the landscape, and in Clare's opinion, destroyed a way of life, with this final break from the past, he assessed his life as one of total failure.

John Barrell has demonstrated that the move from Helpston to Nothborough caused a profound change in Clare's attitude toward his beloved landscape. Rather than viewing the nuances of Helpston as unique or charming, in his memory the natural environment became an abstraction. This radical change in Clare's perspective and thus, his emotional stability, was also triggered by his separation from his childhood sweetheart, Mary Joyce. Though Clare had always been sensitive to his natural surroundings, and began writing poetry in response to nature, Mary's "presence" in the landscape added an important dimension to his way of seeing. As a result of the move from Helpston, Clare felt he was twice removed. All other landscapes seemed foreign, and he was forced to rely on memory in recreating his "Eden" in his mind and in his poetry.

Though they had long since parted, for Clare, Mary was ever present in the landscape of Helpston. He identified the fields of his boyhood with Eden, and Mary was Eve to Clare's Adam. As Robinson points out, this is the conscious pattern of imagery in his poetry, and everything in his boyhood memories of nature assumes a new character, a vividness far beyond accurate natural history, a deeper identity because it is part of what clare called "love's register":

I sat beside the pasture stream When Beauty's self was sitting by The fields did more than Eden seem 
Nor could I tell the reason why (Robinson, SPPJC 183: $\underline{21-4)}$

In this register, the landscape is Eden before the Fall: "not just trees, but every single tree; not just grass, but every blade of grass is a special act of the Creator and participates in the freshness before the fall" (Robinson xvii).

Clare met Mary at the Glinton day school when he was only twelve, and despite their extreme youth, there seems to have been a genuine affection between them. Clare remarks that his heart "would turn chill" and "tremble" when he touched her hand and "fancyd her feelings were the same" because when he "gazed earnestly in her face a tear woud hang in her smiling eye \& she woud turn to wipe it away--her heart was as tender as a birds" (Storey, PJC 14). They were close friends and constant companions and it is unclear why Clare and Mary parted, but apparently her father felt that Clare's social status was inferior and that the relationship should be broken. Though clare did not hold Mary completely blameless and continued to hope for a chance to renew their relationship, as the years passed and a genuine relationship with Mary became impossible, she haunted his imaginative life as "the symbol of innocence, the Eve of his Eden, the first love which was to be the touchstone for all later experience" (Robinson,

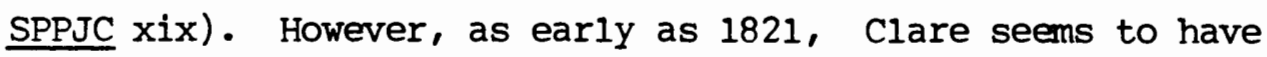
recognized "the essentially ideal nature of his feeling toward her," and describes their early love as "platonic affection, nothing else but love as idea" (Howard 17). Though these comments may have been influenced by his recent marriage to Patty, they still reflect his 
assessment of a real affection for an identifiable woman.

By 1832 he had experienced at least three dreams that featured "a female spirit idealized beyond recognition as any living person, but identified by her voice...as the embodiment of Mary." In these dreams, one of which predates his final meeting with Mary, she appears as "prophetess, femme fatale, and guide through the mystery of life." No longer Mary Joyce, she was by this time an entirely symbolic figure (Howard 17). In discussing these dreams, Clare stresses Mary's connection to his poetry:

These dreams of a beautiful presence a woman diety gave the sublimest consceptions of beauty to my imagination \& being last night with the same presence--the lady divinity left such a vivid picture of her visits in my sleep dreaming of dreams that I could no longer doubt her existence so I wrote them down to prolong happiness of my faith in believing her my guardian genius. (Todd 16)

For Clare, Mary became an "other-world" character. She was his "poetical fancy" and in his poetry during the asylum years, he was constantly attempting to comprehend his experience in a scheme of imagery. As Howard points out, "he began to envisage an intense imaginative relationship, creating out of the real girl, either an ideal of true love, a muse, or a guardian spirit, whichever suited his present state of mind and poetic spirit." And in his adult years, though his attitude toward Mary was complex and shifting, "it developed from a simple regret for a lost opportunity to the grand poetical conception that dominates Child Harold," and, in the end, he 
was "confronted with the final impossibility of uniting his ideal with his real experience" (17-18).

After Clare's and his family's move to Northborough, his emotional and physical heath continued to deteriorate. From his youth he had suffered from seizures and he now complained of severe stomach pains, numbness in parts of his body, and a "prickly feel about the face and temples" (Howard 84). He had quarrels with his publisher, and they eventually parted company, and he grew increasingly morose and difficult to live with. In 1837, when his wife Patty could no longer stand his sporadic behavior, he was taken to High Beech Asylum at Epping Forest, from which he briefly escaped in 1841, trudging the long journey home only to find that Mary Joyce had died three years before. He was allowed to remain with Patty, writing and revising parts of Child Harold, which consists mostly of poems to Mary. In 1841, five months later, he was permanently incarcerated in the Northampton General Lunatic Asylum where he spent his last twenty-three years, fraught with confusion and guilt, believing at times that he had been imprisoned for bigamy because he thought he was married to both Patty and Mary. There he was visited occasionally by his children, but never by his wife. Though he continued to write poetry, he had no reading public, and when he died on May 20, 1864, and his body was taken back to his native village of Helpston for burial in the churchyard, there were no family members to receive it.

\section{John Keats}

John Keats's short life began in Iondon on October 31, 1795, two 
years after the birth of John Clare. Though he never succumbed to madness, his life was marred by a continuous series of losses and separations, beginning with his father's accidental death when he was only nine, and his mother's alcoholism and hasty re-marriage. Upon his mother's death from tuberculosis in 1810, he said: "I have never known any unalloy'd Happiness for many days together: the death and sickness of some one has always spoilt my hours" (Watts 7). Keats, his brothers George and Tom, and his sister Fanny were taken into custody by their grandparents, but John Jennings, the grandfather, soon died, leaving them in the care of his widow, Alice, who from all accounts, provided a happy household for the children. Though the grandfather had left ample financial provisions for the children, because of the legal labyrinth and the untoward disposition of their guardian, Richard Abbey, John and his brother George were often short of funds, neither knowing or having access to their full entitlement. From 1803 to 1811 Keats attended Reverend John Clark's School at Enfield, a progressive boarding school where he received a liberal education, but after his mother's death he was forced to give up school and trained as an apothecary for five years, and then as a dresser to the surgeons, where he learned a variety of skills including bone-setting and tooth extraction, how to clean and dress wounds, and the procedure for cleaning up after surgery. In July 1816 at the age of twenty, he passed his examinations and became licensed to practice independently as an apothecary as soon as he became of age the following year. But, as fellow student Henry Stephens surmised, "Keats was much more interested in literature than in medicine," and 
to his mind, poetry was "the zenith of all his Aspirations--the only thing worthy the attention of superior minds," so Keats thought that "all other pursuits were mean \& tame" (Bate 49 ). As the reading of past poets increased its hold on Keats's imagination and, far from intimidating him, gave him encouragement to write, during the month of October 1816, on the last day of which Keats would become twenty-one, besides writing the sonnet on Chapman's Homer, he was introduced to Leigh Hunt who had already been a vivid model for Keats's poetic style. Shortly after, much to his guardian's surprise and displeasure, he informed him that he planned to rely on his poetic abilities for a livelihood. To Abbey's barrage of protests Keats responded very quietly, "My mind is made up.... I know that I possess Abilities greater than most men, and therefore I am determined to gain my living by exercising them" (Watts 14).

Keats's commitment to writing poetry had been strengthened by his friendship with Leigh Hunt, poet, critic and essayist who was the most important early patron and friend of Keats. In March of 1817, Keats's first book of verse, Poems, was published. Though the earliest reviews were favorable, the volume sold poorly. But Keats was not deterred. He resolved to begin a long poem and arranged for John Taylor (who later took on Clare) to become his publisher. Their association was to be, both emotionally and financially, a source of support for years to come. Keats's goal was to write a four-thousand line poem, Endymion, on the theme of "man striving to become one with his ideals." At first he was lonely, nervous, and blocked, but complied with his plan of writing at least forty lines a day. Through 
his courageous effort over a period of more than six months, he emerged as a mature, thoughtful, self-critical poet, although he was only 22 years old. When Endymion appeared in late April of 1818, the generally conservative reviewers of the day attacked his work "with malicious zeal, as mawkish and bad-mannered, as the work of an upstart 'vulgar Cockney poetaster'" and "consisting of "the most incongruous ideas in the most uncouth language" (Kipperman 179). Keats was hurt but not crushed and wrote to James Hessey on October 8th: "In Endymion, I leaped headlong into the Sea, and thereby have become better acquainted with the Surroundings, the quicksands, \& the rocks..." (Cook 418$)$.

The themes in Endymion parallel Keats's own life quest: the attainment of the ideal through love of the earthly, the real and the ideal becoming one through intense, sensuous love. And there are elements of himself in the suffering of both Hyperion and Apollo in the long poen Hyperion which he began shortly afterwards, in the Autumn of 1818, while he was nursing his consumptive brother Tom. Dwelling on the theme of Hyperion--of the poet's ability to transcend tragic pain and the loss of faith through the creation of beauty in poetry, Keats must have felt the difficulties or even the moral impossibility of rising to a state of cool disinterestedness in the face of Tom's agony, and must have questioned the value of speaking of "inevitable human progress or the birth of the poet" when confronted with such pain (Kipperman 200). After Tom died on December 1, 1818, Keats went to live with Charles Brown at Wentworth Place, now the Keats House, which would be Keats's last real home in England. It was 
here, probably in November, that Keats met Fanny Brawne. Short1y after, on December 25th, they declared their love, and were engaged the following october, 1819, but their marriage was never to be.

Keats's relationship to Fanny Brawne has intrigued lovers of his poetry for generations, and in considering the relevance of the themes of his poetry to the actual events of his life, one is baffled by the inescapable thought that Keats himself was endowed throughout his life with a "kind of foreknowledge" of what was to come, and that he knew, but he did not know, how he would be consumed (Murry, K\&S 14). Keats's letters during the summer of 1818, several months before he met Fanny, reveal that he was obsessed by the thought of a woman's love, believing that her love would serve as a refuge from his pain. In a letter to his friend Reynolds he writes that:

I was never in love yet the voice \& shape of a woman has haunted me for these two days--at such a time when the relief, the feverous relief of poetry seems a much less crime--This morning, poetry has conquered--I have relapsed into those abstractions which are my own life--I feel escaped from a new strange and threatening sorrow--and I am thankful for it. There is an awful warmth about my heart like a load of immortality. (Cook 417)

This was written with regard to an incident involving Jane Cox, an acquaintance he highly admired for her beauty, confidence and sophistication; but from these lines it is clear that even before he met Fanny, he was aware of the conflicts that would arise between his love for a woman and his love for writing poetry. This conflict was 
sharpened after he met Fanny by his realization that he could not hope to marry her unless he made money, and that he could only write poetry when separated from her. Looking back on the summer of 1819 when he took a trip to the coast in hopes of finding inspiration to begin Endymion, he recalls in a letter to Fanny:

My sweet creature when I look back upon the pains \& torments I have suffered for you from the day I left you to go to the Isle of Wight, the ecstasies in which I have passed some days and the miseries in their turn, I wonder the more at the Beauty which has kept up the spell so fervently. (Cook 523)

Keats's desire for love and his commitment to writing poetry were a source of both pleasure and pain, but his belief in the intense beauty they afforded him was the catalyst for both needs, yet intensity was always followed by a sense of pain and 1oss. Shortly after his first separation from Fanny, Keats confided to her the earlier fears he had harbored about falling in love: "I never knew before what such a love as you have made me feel was; my Fancy was afraid of it, lest it should burn me up" (Murry, Keats 27).

After the initial flurry of love letters in the summer of 1819, Keats's feelings of intoxication with love for Fanny became interspersed with periods of depression and listlessness. Although 1819 was for Keats his annus mirabilis as a poet, and he produced "The Eve of St. Agnes" and all the major odes during that year, he was still suffering from the death of Tom, his separation from his brother George who had emigrated to America, as well as his conflicting 
feelings about his love for Fanny. At times, he tried to stay away from her, a gesture no doubt prompted by his realization that he could not marry unless he established himself as a poet, but his attitude also reflects the conflict he expressed in Endymion, that the attainment of the ideal through earthly love depended upon the prior resolve of the man to part from the girl. In this respect, like Clare's Mary Joyce, Keats's Fanny Brawne becomes an "other-world" character. The poetry he wrote to her served as a means of bringing his vision of her as ideal lover and himself as immortal poet into objective expression and reality; but eventually, in quest of his wished-for reality, he began to hope for life through death. In the letter Keats wrote to Fanny in September, his doubts about the possibility of fulfillment of happiness in this life began to surface, and he found his "vision" of her preferable to her actual presence: If I were to see you today it would destroy the half comfortable sullenness I enjoy at present into dow[n]right perplexities. I love you too much to venture to Hampstead, I feel it is not paying a visit, but venturing into a fire.... Knowing well that my life must be passed in fatigue and trouble, I have been endeavoring to wean myself from you. (Watts 44)

As a result of his attempts to "wean" himself from Fanny, in his love poems to her he "speaks as a lone character on a stage," with no real action in the "play" except "the stream of thoughts and the sentiments that flow in protest against a thing which the speaker has no power to change" (Richter 454-A). When Keats's health began to decline and his 
finances had not improved, he must have known he was never destined to share happiness with Fanny. His letters during october reveal that her effect on him was shattering; he is both totally absorbed by her and deeply disturbed:

The time is passed when I had power to advise and warn you against the unpromising morning of my life--my love has made me selfish. I cannot exist without you--I am forgetful of everything but seeing you again--my life seems to stop there--I see no further. You have absorbed me. I have a sensation at the present moment as though I was dissolving. (Cook 519)

Even from the time of Keats's first letter to Fanny, he touches on a note that is to become persistent in his feelings for her and which also surfaces in his letters and poems to her--namely, the association of love and death. He writes: "I have two Iuxuries to brood over in my walks, your Loveliness and the hour of my death" (Cook 484); and in his poems to her, night, darkness, silence, in some ways appropriate conditions of love, imply in Keats's mind their other context, the grave. Walsh claims that the romantic blend of "love, pain, religion and death" is present in the "hectic quality" of Keats's language in the letters and poems, and reveals that Keats's experience with Fanny was never peaceful or serene. Though Keats offered to free Fanny from the engagement when he became seriously i11, at the same time, he was harassed by jealousy and anxiety about her virtue. He tells her "I cannot live without you, and not only you but chaste you: virtuous you" (Cook 533). 
Though Keats and Fanny often embraced and exchanged physical as well as verbal endearments, whether they ever consummated their love is unclear; but some of the moods expressed in his poetry to her, particularly "the ardent and the frustrated, the longing and jealous, and the hopeful and bitter," imply that he remained abstinent, as do his words to Brown shortly before he died: "I should have had her when I was in health" (Watts 46 ).

In February 1820, when Keats was only 25, came the hemorrhage that convinced him he was dying. Despite some periods of remission in the spring, he soon worsened and there was little hope for his recovery. He was now living alone in Kentish Town, but he was fearful and restless, trying to separate himself from Fanny because of the pain his thoughts of her caused him, but this only made him become more ill and agitated. When he was dying, he wrote to Brown: "I can bear to die--I cannot bear to leave her" (Cook 541). Eventually Fanny and her mother nursed Keats in their home at Wentworth Place, but then Keats sailed to Rome to avoid the penetrating cold of the English winter, and never was to correspond with Fanny again. En route, he wrote to Brown imploring him to $100 \mathrm{k}$ after her, and his letter concluded with the following lines:

The thought of leaving Miss Brawne is beyond every thing horrible--the sense of darkness coming over me--I eternally see her figure eternally vanishing.... Is there another Life? Shall I awake and find all this a dream? There must be we cannot be created for this sort of suffering. (Cook 539) On the night of February 23, 1821, Keats died peacefully in the 
arms of his friend severn. Though his last words were intended to comfort his friend: "Severn--lift me up--I am dying--I shall die easy--don't be frightened--be firm, and thank God it has come," he suffered tremendous mental and spiritual anguish during his final days. Just the week before he died, Severn, aware of Keats's dying fears of persecution and eternal obscurity, wrote to William Haslam: ....this noble fellow lying on the bed--is dying in horror....no philosophy--no religion to support him.... he says in words that tear my very heartstrings--'miserable wretch I am--this last cheap comfort--which every rogue and fool have--is deny'd me in my last moments--why this--o! I have serv'd every one with my utmost good--yet why is this--I cannot understand this'.... (Watts 104)

Some twenty years later Severn recalled that on his deathbed "in great emotion at his cruel destiny," Keats told him that "his greatest pleasure had been watching the growth of flowers." His intense love of beauty is reflected in his work, and as Kipperman suggests, "the struggle with aesthetic form becomes an image of a struggle for meaning against the limits of experience." Above all, Keats enjoyed exploring the ways in which beauty, in its own subtle and often surprising ways, reveals the truth, and in his poetry, his was always the quest for truth (217). 
CHAPTER III

JOHN CIARE'S POETIC PROCESS

Though Clare's and Keats's poetic processes are quite different, they converge with respect to expressing feelings of love, pain, and isolation as we shall see in comparing the love poems in chapters $\mathrm{V}$ through VII. But first I would like to explore the individual characteristics of their poetic theories and methods of invention in order to construct a basis on which to draw comparisons between their ways of perceiving, feeling, and ultimately, creating their poetry. Since contemporary reviews of his first volume of poetry, Poems Descriptive of Rural Life and Scenery, in 1820, Howard asserts that the most persistent charge against clare has been that his descriptions are vivid and accurate, but his poems lack the element of thought that characterizes the nature poetry of his contemporaries. Though comparisons of Clare and Wordsworth abound, they are mostly devoted to distinguishing unequivocally great poetry from what is not. In 1921, John Middleton Murry claimed that as a poet of nature, Clare was truer, more thoroughly subdued than Wordsworth, but Clare was not capable of thinking long and deeply as Wordsworth was. Murry remarks that Clare is more akin to Keats than wordsworth, but cautions readers of the vital differences between Keats and Clare: 
the range of his imaginative apprehension: Keats in virtue not only of his imagination, but also of his art. In one respect Clare was a finer artist than wordsworth, he had a truer ear and a more exquisite instinct for the visualizing word; but he had nothing of the principle of inward growth which gives to Wordsworth's most careless work a place within the unity of a great scheme. Wordsworth's incessant effort to comprehend experience would itself have been incomprehensible to Clare; Keats's consuming passion to make his poetry adequate not merely in content but also in the very mechanism of expression to an emotional experience more overwhelming even than Wordworth's would have seemed to him like a problem of metaphysics to a ploughboy. (Murry 8-9, John Clare and Other Studies)

In 1921, Thomas Moult also detected an affinity between the poetry of Clare and Keats in his discussion of Clare's ode to Autumn in Child Harold, but he also makes a vital distinction. He admits that there is something of the quality of Keats himself in the ode, but he claims it is necessary to make a psychological distinction regarding the bulk of their poetry, between the fancy that characterizes Clare's work and the imagination in the work of Keats. Moult believes Clare's fault is that he observed too much, and that his interest lay with "attractive anomalies rather than with their destiny and relation to the universal scheme;" while Keats, in his ode "To Autumn," does not use physical facts for their own sake, but regards natural objects as the symbols by which he expresses his 
aesthetic conception (Storey, Critical Heritage 347-48). Unfortunately, such oversimplifications of Clare's work have stood as standard criticism from his time to the present, but a closer 10ok at Moult's argument will show its inadequacy. He cites the passage:

... And oft as morning from her lattice peeps

To beckon up the sun, I seek with thee

To drink the dewy breath

of fields left fragrant then,

In solitudes, where no frequented paths

But what thy own foot makes betray thy home,

Stealing obtrusive there

To meditate thy end... (Tibble, Poems 3: 5-12)

Though Moult claims that Clare cannot get beyond the physical facts, clearly these lines express far more than the beauty of nature. The structure of the poem itself is an attempt to trace the gradual change and eventual disappearance of autumn. The images convey an impression of fragility and fleeting time as the speaker tries to capture them before they are 1ost. Rather than depicting a literal picture of the landscape, all of nature is personified and the speaker's mind is more operative than his eyes. The words "To meditate thy end," suggest that the scene causes him to become reflective and concerned about other past or potential "ends" rather than merely autumn's inevitable decline.

At the time of Murry's and Moult's assessments of Clare, most of Wordsworth's and Keats's ideas about poetry had already been made available to the public, while Clare's views were evidenced only in a 
few poems and the very little prose that had been published at the time. Subsequent publications of Clare's poetry and the discovery of new manuscripts reveal that Clare possessed an intelligent and sensitive mind. In one of his prose fragments, clare differentiates between the sensory and intellectual pleasure he derived from nature by claiming that "pleasures are of two kinds--one arises from cultivation of the mind $\&$ is enjoyed only by the few," while "the more common pleasures are found by the many like beautiful weeds in a wilderness." He associates the sensory pleasures of nature with "pleasures of the passions," while he feels that the pleasures of the mind are "the most lasting \& least liable to change." Though it is obvious from this statement that he considered himself above average intellectually, he was well aware of his vulnerability because of his lack of formal education, but he defended this deficiency by pointing out that although he was not "wonderfully deep in science, nor so wonderfully ignorant as many have fancied," his "restless curiosity was ever on the enquiry \& never satisfied." And with great humility he admits that although he "never came off victorious," he was "never conquered" (Howard 25-6).

Though Clare gained his reputation primarily as a descriptive nature poet, nature is often depicted metaphorically. His was a special vision because he felt that nature was "the very essence \& soul of Poesy" (Tibble 176). In most of Clare's love poetry, nature is also a touchstone for the quality of his love, and a dominant theme is his longing for a union between himself as poet, his lover, and nature, believing that nature would be enhanced by such a fusion: 
That form from boyhood loved and still loved on That voice--that $100 \mathrm{k}-$-that face of one delight Loves register for years, months, weeks--time past and gone

Her looks was ne'er forgot or out of sight --Mary the muse of every song I write Thy cherished memory never leaves my own Though cares chill winter doth my manhood blight And freeze like Niobe my thoughts to stone-our lives are two--our end and aim is one (Robinson, LPJC $54: 384-92)$

In this stanza the "form" he refers to begins as that of nature, "loves register," but he instantly transforms it into the embodiment of his love, Mary Joyce, who in turn becomes the "muse" of every song he writes--the embodiment of poetry. Thus, nature, love, and poetry are fused into an integral whole, which is the poem. The reverberating relationship between the concrete (nature) and the abstract (Mary) is accomplished metaphorically by the personification of Nature as a woman ("her looks") and by the transfiguration of Mary into "muse."

Because of his awareness of the special powers of the poetic mind and his propensity to combine the pleasures of passion and the pleasures of intellect he derived from nature in his poetry, Clare's quality of perception transcended merely verbal description. Though Clare was interested in words because they were his only means of conveying what he saw, he considered the images he created through 
metaphor, rather than the individual words, the "real art" because they projected more than the literal meaning. Clare found that looking on nature with a poetic eye greatly enhanced the pleasure, and in his method of perceiving nature the images themselves became altered. This alteration revealed to Clare's sensitive mind "not simply a bird, but a hermit; not a snowdrop, but a lovely woman--in short, not an object but a corresponding image which transformed the original object into a source of greater joy" (Howard 30).

Clare felt that artifice (the use of unnatural images in metaphor), hampered his direct communication from nature to poetry. Rather than inventing and arranging new images into works of art as he saw his contemporaries doing, he used his poetry as a means of communicating his special vision of the natural world. Of Keats he commented that "his descriptions of scenery are often very fine but as it is the case with other inhabitants of great cities he often described nature as she appeared to his fancies \& not as he would have described her had he witnessed the things he describes" (Tibble 223). He also held disdain for poets who allowed an awareness of their audience to interfere with their true feelings and felt the vision of the world they present in their poetry becomes affected because they strive "to hit all tastes, by only writing what they fancy all feel" (Howard 30).

In order to explain how he perceived nature with a sensitivity not common to all men, clare used the term "taste." Although during Clare's time, "taste" was associated with the critic's power of discrimination as applied to works of art, clare extended the meaning 
of the term to describe "the poet's own facility to grasp intuitively the inherent beauty of his environment" (Howard 31). His poem "Shadows of Taste" explores the various tastes of nature and of man, "Taste with as many hues doth hearts engage / As leaves and flowers do upon natures page." The essence of the poem is that all choose joy in a peculiar way, and that taste is associated with what Howard refers to as a "universal wisdom" shared by animals, birds, and flowers as well as men. Yet the poet ranks the highest because in his relationship with nature he is able to capture the joy in the poem forever, whereas physical sensations of joy are fleeting:

A face of beauty in a city crowd Met--passed--and vanished like a sumer cloud In poesy's vision more refined and fair Taste reads oerjoyed and greets her image there Dashes of sunshine and a page of may Live there a whole life long one summers day A blossom in its witchery of bloom There gathered dwells in beauty and perfume The singing bird the brook that laughs along There ceaseless sing and never thirsts for song A Pleasing image to its page conferred In living character and breathing word Becomes a landscape heard and felt and seen Sunshine and shade on harmonizing green (Robinson, SPPJC 112)

Clare's excitement about the poetic process is evidenced in the verse 
itself by a gradually increasing sense of pleasure, as the poet reflects on the diverse images and renders them to poetry. The pleasures of passion and intellect are at once satisfied, and the beauty of nature lives through the "breathing word." Metaphorically, the poem becomes "a landscape heard and felt and seen."

In Clare's theory of poetry, "taste" must be allied with "genius" in the poet's mind in order for him to create poetry, and complete solitude is required to initiate this mental activity. In "Dawning of Genius" he describes genius as "a pleasing rapture of the mind / a kindling warmth to Learning unconfin'd" (Robinson, EPJC 451: 1-2). While he considered "taste" the faculty that enabled the poet to appreciate beauty and to select particularly pleasing images from nature, he viewed genius as the faculty which acts upon the perceived images in a state of mental excitement and bestows on them metaphoric or symbolic qualities. Though Clare's poetic thought was stimulated by solitude as he communed with nature, his experience was seldom passive because his mind responded to silence in much the same way as Coleridge does in "Frost at Midnight," where the calm of solitude "disturbs and vexes meditation with its strange and extreme silentness" (Jackson 87). In this passage solitude evokes painful thoughts:

Hail Solitude still Peace and Lonely good Thou spirit of all joys to be alone My best of friends these glades and this green wood Where nature is herself and loves her own The heart his anguish here I make it known 
And tell my troubles to the gentle wind

Friends cold neglects have froze my heart to stone

And wrecked the voyage of a quiet mind

With wives and friends and every hope disjoined

(Robinson, LPJC 87: 1274-82)

While in this passage, solitude induces a calming effect:

Sweet solitude thou partner of my life

Thou balm of hope and every pressing care

Thou soothing silence oer the noise of strife

These meadow flats and trees--the Autumn air

Mellows my heart to harmony... (Robinson, LPJC 66: 732-736)

Whether Clare's poems express pain or pleasure, the impulse to write poetry occurs while he meditates on nature in a state of isolation and silence.

The movement from natural object to thought provided clare's mind with the material for expressing poetry, and this process culminated in the poet achieving a new state of mind. An example of the movement from natural object to abstract thought is illustrated in this stanza:

How sweet are the glooms of the midsummer even

Dark night in the bushes seems going to rest

And the boscm of Mary with fancys is heaving

Where my sorrows and feelings for seasons were blest

(Robinson, LPJC 42: 59-62)

In the poet's observance of nightfall, the landscape is transfigured into the "heaving bosom" of Mary while still retaining its natural qualities. Rather than substituting the abstract vision for the 
concrete one, what occurs in this moment of imaginative perception is a fusion of their properties. The ambivalence of "dark night in the bushes seems going to rest" suggests that the scene before him is vital, yet fleeting. While his purpose is to capture the scene before it is lost, the image he tries to preserve is not merely the landscape at twilight, but also the presence of Mary the scene evokes, so a fusion of the concrete and abstract results in the creation of the literary, metaphorical image wherein Mary's breast and the landscape become one within the poem. The poem operates on the literal and abstract level simultaneously, and as Clare accomplishes the imaginative fusion of the two worlds, the result is a heightened awareness and intensity of feeling which Clare associated with the climax of the poetic process. Poetic climaxes such as this one are not reserved for the final 1 ines of Clare's poetry, but occur intermittently throughout the poems.

An important aspect of Clare's poetic theory is his belief that in order to experience heightened perception, the mind must be engaged in an unselfconscious, objective intellectual activity not unlike Keats's theory of Negative Capability. He addresses this unconscious aspect of the poet's mind in the opening of Child Harold:

And he who studies natures volume through And reads it with a pure and unselfish mind will find Gods power all round in every view As one bright vision of the almighty mind (Robinson, IPJC 42: 42-5)) clare's reference to "Gods power" suggests he felt that his poetic 
impulse was a gift. In one of his most frequently quoted poems he insists: "I found the poems in the fields / And only wrote them down" (Tibble, Poems 383-4). Similar to Milton, Clare felt his role as a poet was that of transcriber, but his muse was nature and all that nature represented to him.

Often, the end of the poetic process left clare despondent rather than tranquil, and many of his poems about poetry end in disappointment:

Though they are blazoned in the poets song

As all the comforts which our lifes contain

I read and sought such joys my whole life long

And found the best of poets sung in vain

But still I read and sighed and sued again.

And lost no purpose where I had the will

I almost worshiped when my toils grew vain

Finding no antidote my pains to kill

I sigh a poet and lover still (Robinson, LPJC 56: 435-43) His inability to find solace through poetry, the fact that when his "toils grew vain," he could find "no antidote" his "pains to kill" can be attributed to his recognition of the inadequacy of language to convey the full impact of his experience. In Child Harold he asks "Can language paint the soul in those blue eyes" (78, Stanza 73), and the forlorn fragment, recorded by the house steward at the Northampton Asylum while Clare was there is testament to Clare's sense of language's inability to convey his emotional experience: "Language has not the power to speak what love indites / The Soul lies buried in 
the ink that writes" (Robinson IPJC 1015).

The problem is one which has concerned modern poets in particular, a phenomenon which René Welleck referred to as the "the cult of silence." Crossan argues that clare is a fine example of Wellek's observation that since the dawn of history many have felt that language fails to express their deepest emotions and insights, that the mystery of the universe or even of a flower eludes expression in language. This failure of words is never so acutely felt as when the poet tries to express his love for a woman throughout the lengthy poem Child Harold:

Abscence in love is worse then any fate

Summer is winters desert and the spring

Is like a ruined city desolate

Joy dies and hope retires on feeble wing

Nature sinks heedless--birds unheeded sing

Tis solitude in citys--crowds all move

Iike living death--though all to life still cling

The strongest bitterest thing that life can prove

Is wamans undisguise of hate and love (Robinson, LPJC 71: 864-72)

The irony is, of course, that clare succeeded in writing some excellent lyrics despite the limits imposed by language. As Wellek noted, the artist's dissatisfaction with language can only be expressed by language.

Clare attempted to compose his poems during or immediately after the "rapturous" poetic experience itself. In his autobiography he 
writes that "Poetry was a troublesomely pleasant companion annoying and cheering me at my toils--I could not stop my thoughts \& often failed to keep them till night so when I fancyd I had hit upon a good image or natural description I usd to steal into a corner of the garden \& clap it down" (Tibble, Prose 32). As he wrote his publisher, "the Muse is a fickle Hussy with me--she sometimes stilts me up with madness \& then leaves me by the wayside with no more life then whats mortal \& and that nearly extinguishd by mellancholy forbodings" (Howard 51). The extent to which clare relied on immediate experience and how disconsolate its departure left him is evidenced in another letter to his publisher regarding his sonnet "To the Memory of John Keats":

I did it as I felt it at the moment your melancholy news woud give me pause for reflection--I wishd I had made an Elegy afterwards of it as my ideas was crampt they flowed freely \& I could have gone a great length but words are of little value--be as it will I can do nothing more now--the moment is gone I cannot call it back I wish I could (Tibble, Letters 109).

Though Clare realized that his immediate mood was crucial in composing poetry, when intense experiences came to him less and less, either because of the passing of time or his physical removal from familiar natural surroundings, he was forced to rely on memory. But, like Wordsworth, he considered memory only a shadow of the original experience: "The spring of our life--our youth--is the midsummer of our happiness--our pleasures are then real \& heart stirring--they are 
but associations afterwards... our minds only retain the resemblance" (Tibble, Prose 225). In contrast to Wordsworth, Clare's loss of youth was far more severe because it meant the loss of nature, home, and love. In Child Harold he bemoans his dreary situation: Where are my friends and children where are they The chilaren of two mothers born in joy One roof has held them--all have been at play Beneath the pleasures of a mothers eye --And are my late hope's blighted--need I sigh Hath care commenced his long perpetual reign The spring and sumer hath with me gone bye Hope views the bud a flower and not in vain Long is the night that brings no morn again (Robinson, LPJC $76: 984-92)$

Howard remarks that the diversity of Clare's poetic expression stems from the fact that his method of composing poetry allowed him to explore his intricate, often ambivalent responses to love, nature, and his own personality. But the escalation of complexity in his poetry occurred as he became increasingly estranged from the beauties of nature--first, by his move from the familiar landscape of Helpston, and later in life because of deteriorating physical and mental health during his confinement in the asylum. During this last period of his life, his imagery reflected this estrangement in its unnatural and surreal qualities. Distortion of natural imagery becomes a predominant feature in Child Harold:

Now Come the Balm And Breezes of The Spring 
Not With The Pleasure's of My Early Days

When Nature Seemed One Endless Song To Sing

A Joyous Melody And Happy Praise

Ah Would They Come Again--But Iife Betrays

Quicksands and Gulphs and Storms That Howl and Sting

A11 Quiet Into Madness And Delays

Care Hides The Sunshine With Its Raven Wing

And Hell Glooms Sadness Der The Songs Of Spring (Robinson,

LPJC 77: 993-1001)

Clare's close identification with nature as a source both beauty and poetry, once the most positive force behind his world view, is now transformed into a vision of darkness in which feelings of betrayal, despair, and madness are his only companions as he hovers on brink of he11. This stanza reflects the speaker's complete disavowal of the possibility of happiness in a world where "hell Glooms sadness" over a11, and also reveals his uncertainty about his own future as poet, since there will be no songs to sing. Nature, as well as the poet himself, are in a state of transition (or chaos), with the "balm and breezes" turning to "quicksand, gulphs, and storms," and reality is a world of nightmares.

In exploring clare's poetic process it is evident that he possessed an intelligent and sensitive mind, and that he thought seriously and deeply about the function of poetry. Unfortunately, because he composed his most complex poetry when he was confined to an insane asylum, after he had lost his hame, loved ones, and reading public, he did not, like Keats, attempt to leave any record of his 
philosophy of poetry. Consequently, his awareness of the special powers of the poetic mind and his propensity to combine the pleasures of passion and intellect, thereby achieving a perception that transcended merely verbal description, have been discounted by most critics and long overlooked by the few readers of clare today. 
CHAPTER IV

KEATS'S POETIC PROCESS

What distinguishes Keats and Clare from other Romantic poets is their extraordinary sensitivity to the impression of the moment, and their use of everyday life experiences in their poetry. Keats had a penchant for creating highly complex metaphorical states. As Gittings points out, Keats could and did transform almost any experience into poetry, in an instantaneous and instinctive process. The vital force in all his poetry is his ability to let his imagination act on every aspect of life, so that the result far transcended the original. From his earliest boyhood Keats had an acute sense of the beauty of the natural world, and as Kipperman notes, it was this sense of beauty which eventually caused him to seek his mind for images which could best express his feelings.

As far as we know, Keats did not even try to write poetry until the age of eighteen or nineteen, and what he did write from then until he was twenty-one (with the exception of "On First Looking into Chapman's Homer") was mediocre. What is astounding about Keats's life is the extent of his achievement--his astonishingly rapid development as an intellectual and a writer in the course of only four or five years. Though in his brief life, Keats never formulated a set philosophy of poetry as Wordsworth, Coleridge and Shelley managed to 
do, in his letters he left a remarkable record of his thoughts on his own career and its relation to the history of poetry. Keats saw both beauty and truth in nature and possessed a romantic faith in the imagination. He considered the poet's mission a spiritual and imaginative quest to create beauty through his ability "to perceive the transcendent or the enduring in a world of suffering and death." For Keats, this quest for a transcendent truth can only be expressed in terms of "an intense, imaginative engagement with sensuous beauty" (Kipperman 194):

I am certain of nothing but of the holiness of the Heart's affections and the truth of Imagination--what the imagination seizes as Beauty must be truth--whether it existed before or not--for I have the same Idea of all our Passions as of Love they are all in their sublime, creative of essential beauty. (Cook 365)

No doubt the series of losses and dislocations that pursued Keats throughout his life contributed to his mature sense that his vocation as a poet must involve an exploration of poetry's power to bring comfort and meaning to human suffering.

Bate argues that all Keats's poetry, from his first attempts to the rapid progress in his maturity, evidence that his poetic endeavors were inseparable from certain qualities of character which he esteemed and exemplified throughout his life: courage, charity and sympathetic awareness of others, humor, good sense, and above all, honesty. These qualities constantly operated through the powers of his imagination which was at once "steady, sane, clairvoyantly empathic, and humanly 
wayward" (Bate, Keats, Intro., 3). Though he was always pursued by financial troubles, at the age of eighteen he declared his intention to become a poet. At times he wavered in his resolve and considered resuming his medical career by becoming a surgeon, but the idea of forsaking poetry was most likely a response in a moment of despair rather than a rational plan. He equated the poet's endeavor to that of a surgeon and reverenced Apollo, god of healing and poetry, as his "tutelary diety" because of his identification with human suffering. In The Fall of Hyperion he casts the poet as "a sage, / a humanist, physician to all men." He conceived of the art of poetry as a means of entering the suffering world and mitigating its pain (Cook $\mathrm{xx}$ ).

Keats's sense of the past is as vital as the present in his poetry. In a letter to his brother and sister-in-law he writes that for him, "manners and customs long since past whether among the Babylonians or Bactrians are as real, or even more real than those among which I now Iive" (Cook $\mathrm{xxv}$ ). He was an avid translator of ancient works, and the act of "translation" he carried over to his own poetry. The Elgin Marbles, Chapman's Homer, and the town on the Grecian Urn provide direct access to other countries and other times. Like many of his contemporaries, Keats was drawn to Chatterton's poetry because it was exotic and mysterious. Chatterton's "pseudo-Medieval" poetry appealed to an age which enjoyed encounters with the Gothic past and the audience was not greatly concerned about the genuineness of the occasion. As Watts points out, Keats's worthiest debt to Chatterton, taken from the "Rowley" poetry, was the Third Minstrel's son of Autumn in AEIla from which he obviously 
recalled Chatterton's "fair ruddy apples" which "bend the tree unto the fractyle grounde" (line 303), when he wrote the lines in "To Autumn": "To Bend with apples the moss'd cottage-trees, / And to Fill all fruit with ripeness to the core" (Cook 324: 5-6). And Chatterton's lines from "Kew Gardens": "Woman, of every happiness the best,/ Is all my heaven,--religion is a jest," are echoed in several of the love poems he wrote to Fanny Brawne.

Keats wrote his first and last poems in the manner of Spenser, who was as much a "Middle English pasticheur" as was Chatterton (Cook $\mathrm{xxv})$. The first of these poems, "Imitation of Spenser," is the work of a young poet trying to find his voice by speaking in the manner of someone else. Though the verse is somewhat clumsy, Kipperman argues that his poetic ear is acute as he boldly attempts to contrive a powerful poetic image to create a dreamy scene: "Ah! could I tell the wonders of an isle / That in the fairest lake had been / I could e'en Dido of her grief beguile" (Cook 1: 19-21). In his last poem, "In after time a Sage of mickle 1ore," he uses the spenserian idiom with confidence to engage not only with Spenser, but with contemporary politics (Cook xxv):

In after time a sage of mickle lore, Yclep'd Typographus, the Giant took And did refit his limbs as heretofore, And made him read in many a learned book, And into many a lively legend look; Thereby in goodly themes to training him, That all his brutishness he quite forsook... (Cook 331:1-7) 
Despite Keats's admiration for Chatterton and Spenser, Shakespeare's works inspired his deepest and most joyful relationship to the past. Even when he complained that Shakespeare "has left nothing to say about nothing or anything," he was not overwhelmed, but in awe. Cook asserts that Shakespeare's phrases enter Keats's letters and poems in a way that is too intimate to call them quotations. When he tells Fanny Brawne how his "sense ached" at a vision of her which haunted him, he is not mimicking Shakespeare, but rather, Shakespeare inspired Keats and informed his work in a way which allowed him to discover and magnify his own literary sentiments. Of the five poems he wrote to Fanny in the autumn of 1819, three were in the form of Shakespearean sonnets. As Bate points out, although Keats had given up the sonnet form months before for use in what he referred to as his "serious writing," the situation was very different now. Racked by disease, he was turning to Fanny with desperation, rather than with the conflicting feelings and the reservations he previously held regarding their relationship. Curiously, at this time, the "simple" sonnet form came most easily to Keats in working out his most perplexing problems.

Like John Clare, Keats experienced poetry in a way that was intensely physical. The lines in Chapman's odyssey describing the shipwrecked Odysseus, "the sea had soaked his heart through," and the "sea-shouldering whale" of the Faerie Queen thrilled him because they metaphorically conveyed the tension between the animate and inanimate, endowing the images with a strong impression of physical presence. Keats's intensely physical sense of language extends to the idea that 
a poem is possessed of an almost "muscular strength," and describes himself as an "athlete of the imagination," trying [himself] with mental weights," thereby strengthening his imagination (Cook xxvii).

Though Kipperman cites that Keats's imitative poetry was a response to his awareness of the gap between his small voice (or the concrete experience of any individual) and the "sublime limitlessness of a great and distant imagination," his more mature works, particularly the odes, are the expression of the irresolvable contrarieties of experience (187). Using one of his best known metaphors Keats describes human life as a Mansion of many apartments which contains "the infant or thoughtless chamber in which we remain as Iong as we do not think," and the "Chamber of Maiden-Thought" to which we are impelled when we fall from the state of innocence. Here knowledge is exhilarating, but soon discloses that "the world is full of Misery and Heartbreak, Pain, Sickness and oppression." Keats believed that poetry in his era would become an exploration of those "dark passages," as well as the questioning of its own processes of interpreting and articulating concrete experience (Cook 397).

As a result, what Keats attempted to achieve in the great odes--prolonging of fulfillment through a successful union of the ideal--of the heart's desire--and reality, Bate argues that with the exception of "To Autumnn," he was never able to realize such concrete resolution where the poet himself is completely absent and there is no "I" or suggestion of discursive language. The major themes of his great odes "Nightingale" and "Grecian Urn" are echoed in his poems to Fanny Brawne, and the quest for resolution takes the form of a 
distinct process as the speaker moves from dramatic debate, to protest, and then to qualification without ever actually securing his heart's desire--the creation of a genuine paradise. In this sense, like Clare, most of Keats's poetry is an attempt to quell contending passions by metaphorically creating a state of order and repose. In the Fanny poems we see the same process of symbolic debate in which a "dominant symbol or concept, after being postulated at the start, becomes a motif in a counterpoint of withdrawal, qualification, and partial return" (Bate 619). This movement is particularly evident in Keats's first version of the sonnet "Bright Star." Though the poem opens with the speaker longing to be as steadfast and detached as the star, as the poem progresses, he discovers that this state is not completely adequate after all, so he begins to qualify the properties of the star and to partially withdraw from his former conception of its symbolism by the use of negatives:

Not in lone splendour hung aloft the night; Not watching, with eternal lids apart, Like Nature's devout sleepless eremite (Cook 325: 1-3) The real desire is not what the star signifies in keeping continual vigil in genuine detachment. Instead, the speaker longs for a state of being "half-passionless," a state devoid of the limitations inherent in the dilemma of being human, where he can remain somewhat detached yet still enjoy the pleasures of passion, without pain, without end. (Keats's revised version is markedly similar, with exception of the exclusion of the "Not" in line three and more polished language, but the overall implication and tone remain 
unchanged.)

Like Clare, Keats was highly receptive to immediate experience. His friend Severn remarked that during the year 1817, he noticed the development of Keats's "power of sympathy" (a kind of imaginative identification valued in Keats's day as the hallmark of poetic sensitivity). Keats was moved to an unusual degree toward almost "sensory identification" with things around him: "Nothing seemed to escape him, the song of a bird and the undertone of response from covert or hedge, the rustle of some animal.... The humming of a bee, the sight of a flower, the glitter of the sun, seemed to make his nature tremble" (Kipperman 191). Similar to Clare, who saw poetry as the fusion of the pleasures of the passions with the pleasures of the intellect, Keats was also aware of the importance of the imacginative faculty of the intellect in the experience of pleasure, yet he felt that pleasure was never bereft of pain. The central meanings of his great odes emphasize his personal belief that pain, or at least melancholy, is inseparable from pleasure in this life. In "Ode to Melancholy," the lines "Aye, in the very temple of Delight / Veil'd Melancholy has her sovran shrine" (1ines 25-6), immediately following the speaker's reference to "aching Pleasure nigh," imply that even the ecstasies of sexual pleasure are accompanied by feelings of sorrow. Keats felt that the intensity of pleasure was proportionate and dependent upon the same intensity of displeasure, and that this tension operated in all aspects of mortal experience. Through poetry he attempts to resolve these tensions, but, like clare, the poetic process itself often leaves him despondent because of its intensity. 
Similar to Clare's association of "taste" with the mental faculty of selecting pleasing images for his poetry, Keats also equates "taste" with poetic vision, but the muscular strength of his verse reveals that Keats's was a tactile way of seeing. In the lines "To taste the luxury of sunny beams" ("I Stood Tip-Toe," Cook 48: 74), and "Taste the music of that vision pale" ("Isabella," Cook 197: 392), taste has a far greater immediacy than a word like experience, and as Watts argues, presses the diction toward synaesthesia, a deliberate fusion or rearrangement of different kinds of sense experience. In "To Fanny" the speaker, a jealous lover, asks "Who now, with greedy looks, eats up my feast" (Cook 329: 17); in "I cry your mercy..." he likens his mind to a "palate" which has lost its "gust" (Cook 329: 13-14); and in "What can I do..." he claims that "touch has a memory" (Cook 327: 4). In Keats's use of sensuous verse, he creates a sustained analogy which drives the images into the realm of heightened experience by endowing them with qualities which they normally would not possess. The imagery is not as much concerned with replacing one sense experience with another as it is with amplifying the immediate experience, thus lending the particular sensation greater dimension and depth. Blackstone points out that Keats's tendency to jumble or fuse sense experience in his poetry is consistent with his belief that poetic and artistic truth are united through sensation. So heightening the experience in this manner would bring the poet closer to truth.

Keats believed that only through love for the earthly is the ideal reached, "the real and ideal becoming one through an intense, 
sensuous love that leads to a fellowship with essence." The theme of a mortal's love for an ideal figure that proves either "illusory" or "redemptive" was a continuing source of exploration for Keats, as was "the paradox of redemption or transcendence evolving from a fuller engagement with human suffering" (Kipperman 193). In "Ode to Melancholy," the paradox of the simultaneously eternal yet transient Joy, "whose hand is ever at his lips bidding adieu" generates an "oddly vivid picture of a smiling figure, ever receding yet never vanishing." These paradoxes are similar to Keats's thoughts while dying, when he said of Fanny Brawne, "I eternally see her figure eternally vanishing," and they become the major themes for his love poems where the speaker's lover is never within his grasp (Cook 539). Similar to Clare's poetic process, Keats relied on his imagination to select, order, and inter-relate the images he perceived in an attempt to arrive at an ideal vision. Though both Clare and Keats sought to come to terms with earthly existence by creating acceptable, albeit metaphorical, situations through their poetry, Keats more strongly emphasized his belief that poetic images were "truth-seeking" devices, while the world clare created through metaphor was the only "truth" he could bear. Keats insisted that the true artist must adhere to a duality of vision because holding only a single perspective of life obscures its intensity. This stance is evidenced in a letter he wrote to his brothers in December of 1817, when he criticized a painting by Benjamin West for his lack of vision. Keats complained that in the painting "there is nothing to be intense upon; no woman one feels mad to kiss; no face swelling into reality," 
and insisted that "the excellence of every Art is its intensity, capable of making all disagreeables evaporate, from their being in close relationship with Beauty and Truth" (Cook 370).

Keats's best-known doctrine, Negative Capability, he defined as the quality of being capable of experiencing "uncertainties, Mysteries, doubts, without any irritable reaching after fact \& reason" (Cook 370). He coined this phrase when describing Shakespeare's genius and later applied it to illustrate how he used poetry as a means of transcending reality by allowing experience to speak through him without allowing himself to interject his personal emotions or perspectives. Through the poet's total engagement with the object, Keats felt that both the conscious soul and the world were transformed by a vital interconnectness in which beauty and truth would be found. Kipperman suggests that this transformation is art's "truth" because of its alliance with concrete human experience, and that its "beauty" is its ability to abstract and make universal the enduring forms of the heart's desires.

All of Keats's poems to Fanny Brawne are, in effect, an example of the failure of the speaker to exercise Negative Capability--that is, the ability to become so fully absorbed in an object that one loses all personal emotions, habits of perception, and habits of feeling and thought. For example, in "To Fanny," except for the first stanza which is an invocation, the poem consists of one long, fluctuating image of his conception of his lover: her appearance, her moods, her inconstancy, and the specifics the speaker lends to her image gives the scenes he describes a kind of reality. Though the 
reality he creates is dismal, it is also specious because both the content and the emotional coloration of the scenes he portrays are determined not by his love's actual reality, but by his interjection of self and, hence, his own mood at the time. The speaker's resolution at the end of the poem--that the dream is preferable to reality--is merely an imposition of his own values and state of mind. The "dream" he creates metaphorically is a state where he can experience intense emotions without the consequence of actual emotions associated with love--the pain, longing, jealousy, fear, and uncertainty.

Though Keats believed in the transforming power of art, many troubling questions regarding the value and function of poetry remained to be worked out in his letters and poetry. In particular, he wondered if the artist did not demand more answers from real life than the disinterestedness his theory of Negative Capability could offer, whether the "truth" of experience was only that pain accompanies all joy and cannot be transcended, and whether art does nothing more than deflect attention from the knowledge of inevitable loss and death that comes with being mortal. These questions he continually explored in his poetry with varying results. 
CHAPTER V

IIMBO

Though Clare and Keats intended that the end result of their love poetry create, at least metaphorically, an ideal state where they could enjoy sustained fulfillment in the company of their lovers, I will demonstrate that the end result is usually a delusive attempt on the part of the poets to magically possess the absent person, whether through memory, dream, or meditation on nature. The metaphorical sense generates instead a kind of pseudo-reality in the world of the poem wherein the speakers become confined or imprisoned in a state which I describe as "limbo." For example, in Clare's "An Invite to Eternity," the speaker entreats his lover to go with him "To live in death and be the same / Without this life or home or name / At once to be and not to be" (Robinson, LPJC 349: 19-21). And Keats's speaker sets up momentary illusions of being united with his love in such ambiguous states as "Awake and for ever in a sweet unrest" in "Bright Star," or in "the sweetness of the pain" in "What can I do to drive away" (Cook 325: 12; 329: 54). In the poets' attempts to "remake" reality, the poetic language they incorporate is intended to reorder their worlds by changing their perceptions of their situations from despair to optimism, and in the process, they are also striving for truth. However, in these passages the new reference the metaphors 
provide--a union of the speakers with their lovers--is paradoxical. What happens is not the suppression of the speakers' immediate despairing circumstances, but their profound alteration by the workings of the ambiguity of the message itself. Clare's speaker wishes to live in death; Keats's opts for irreconcilable states of "sweet unrest" or sweet pain. The supremacy of the metaphorical state over the speaker's actual circumstance does not obliterate the circumstance, but makes it ambiguous. What results is a double-sensed message which finds correspondence in a split addresser (the speaker), a split addressee (the 1over), and a split reference (the speaker's actual circumstance). In these examples the split reference suggests a tension between the ordinary reference and the new one the metaphor provides. Similar to the preambles to the fairy tales of the Majorcans--"Aixo era y no era" or "it was and it was not"--Clare and Keats attempt to interject the real (what is) into the ideal (what is not). Many instances of split references can be found in their love poems.

Although suspension of reality is a necessary step in the poet's imaginative process of discovering new ways of "redescribing" the world, as Sartre emphasized, to imagine is to address oneself to what is not. Though clare and Keats generate split references by creating fictions through metaphor, and the intended result is that the fiction will replace reality and provide new, positive insight, often the process backfires and the desired transition is never effected. Instead, the speakers of the love poems remain poised on the threshold between two different worlds--the referential or real world and the 
imagined ideal world they hoped to achieve.

Although the creation of threshold states is most often discussed by critics in connection with Keats's poetry, it is important to note that Clare has a similar tendency to create such divisional states in his asylum poetry; and, in fact, the entire notion of threshold states is a negative outcome of the metaphorical structure of Romantic poetry which, according to Northrop Frye, "tends to move inside and downward instead of outside and upward, so the creative world is deep within, as is heaven or the place of the presence of God" (Chilcott 243).

In describing the actual process of creating threshold states, Cedric watts points out that one of the features that gives distinctive character to the work of a particular poet is the presence of an imaginative nexus or linkage-point: "a preoccupation with certain states of being which act as a recurrent imperative (perhaps seldom recognized fully by the artist's conscious intelligence) during the creative process" (149). Though Keats is best known for combining sensuous subject matter with sensuous diction, and Clare for the lyrical purity of his songs and the unique descriptive style of his nature poems, in the love poems, their imaginative nexus is the urge to depict a limen or threshold. Through their use of metaphor, both attempt to depict a transitional state--a moment or phase of transition from one mode of perception or being to another in which the real becomes fused with the ideal; but what actually occurs is a heightening of the ambiguous status of the modes of perception or being on each side of the threshold. Though in the poems the speakers, often suffering from the pain of intense love, attempt to 
achieve a more pleasing transitional state by moving from one mode of perception to another, whether by dwelling on thoughts of the lover, nature, self, or a combination of these, at the conclusion of the poems, they usually fail to effect the transition, or if they do, the resulting state is so ambiguous that it is hardly discernible whether or not they have made any sort of progression toward the desired ideal state of truth, beauty, love, peace of mind, or whatever they were seeking to begin with. In other words, they seem to remain poised on the threshold, caught between the two opposing states the poems describe.

In the works of other Romantic poets such as wordsworth or Shelley, either the transitional states are not so diversely prominent, or the modes of being before and after are less ambiguous and thus generate a much stronger impression of change for the better or worse. For example, in Wordsworth's ode "Intimations on Immortality," no remarkable change is apparent in the speaker's perception by the end of the poem. He begins by reminiscing about how all of the earth and "every common sight" seemed "appareled in celestial 1ight" in his youth, and remarks that "the things which I have seen I now can see no more" (Gill 297: 2-8). At the end of the poem, he is still of the same mentality as when he began and merely continues the dialogue he started more than 200 lines earlier, surmising that he can still enjoy nature, but nature will provide a constant reminder that he can never recover the way of seeing he enjoyed in his youth: "To me the meanest flower that blows can give / Thoughts that do often lie too deep for tears" (Gill 302: 205-6). In 
contrast, Watts points out that Shelley's emphasis is usually on a transitional cycle which tends to be progressive. For example, he emphasizes the value of rebirth, as in "Ode to the West Wind" where he offers hope of a better world for mankind, as well as the coming of spring.

In Clare's love poetry the conscious pattern of imagery is nature as "love's register," in which his boyhood memories assume a new character, a deeper icentity, a vividness far beyond natural history because of his memories of Mary Joyce, his first love, from whom he has long since parted. Though Wordsworth felt the same kind of losses when dwelling on his youth, he was able to take an objective approach to his highly subjective experience and managed to separate the present from the past. Clare cannot do this. Instead, in Child Harold and other asylum poems, he uses his memory of Mary and the estranged landscape of High Beech and Northampton, and attempts to recreate "Eden" by interjecting Mary's presence in all that he sees. In the process, Mary becomes a symbol of the ideal, and he is confronted with the impossibility of uniting this ideal with his real experience, and so the threshold remains intact.

The overall structure of Clare's Child Harold is markedly liminal because the speaker is preoccupied with creating different, though often ambiguous, phases of transition. The enveloping forest and its opposite, the exposing fen or plain, are controlling images in the poem and give it a definite sense of development, but their significance becomes interlinked and confused by the speaker. Though the speaker, as poet, is communing with nature as he addresses the 
beauty of the forest in the poem he is composing, the forest is also a source of confinement because while there, he is isolated from "home love and woman" (Robinson, LPJC 46: 180). In the poem, nature itself is a liminal object, the threshold between the permanent and impermanent. In the early part of the poem, because he is unable to effect the imaginative leap whereby he can make Mary's presence felt in the landscape, the speaker attempts to compensate for his beloved's absence by emphasizing his affinity with the vast forest and by perceiving it metaphorically as his "queen." The mood begins in complete solitude as he wanders alone, but in his solitary walks, the threshold induced by the natural landscape is one of enduring definition and receding flux. The beautiful hill of fern "swells on," and "Nature is with [him]--morning noon and gloaming" (Robinson IPJC $46: 171,176)$. The predictability and constancy of nature alone causes the speaker to feel ambivalent. The "palace green" offers both release and longing, and Clare's use of gerunds, whether verbal or nounal, impart a sense of changelessness amid the cyclical nature of the landscape from which there seems no retreat:

Nature is with me--morning noon and gloaming

I write my poems in these paths unseen

And when among these brakes and beeches roaming

I sigh for truth and home and love and waman (Robinson, LPJC $46: 176-80)$

The speaker's mobility itself becomes an enigma because he seems eternally locked in the forest. He is only able to "sigh" for the fact that he is unable to effect what he desires, not even in a 
fleeting vision.

The middle of Child Harold is dominated by the speaker's emotional search for Mary, and the prevailing image is the fen. Freed from the confines of the forest, feelings of insecurity overwhelm him because he is no longer "hid" in "paths unseen," but exposed. Surrounded by the starkness of the fens, his vision unimpeded by the massive forest growth, he is confronted with the undeniable fact that not only are he and Mary separated, but that her absence is final. However, in his very acceptance of this impossibility, he skews the truth and Mary's absence itself becomes ambiguous because it is all-encompassing--vaster than the forest, larger than nature, bigger than 1ife, : "Mary's abscent everywhere" (Robinson, LPJC 63: 650).

At other times, as a result of the impotence of memory or his depressed mental state, his mind is unable to resurrect the past, either nature or Mary:

My Mind is Dark And Fathomless And Wears The Hues of Hopelessness Agony and Hell No Plummet Ever Sounds The Souls Affairs There Death Eternal Never Sounds the Knell There Love Imprisoned Sighs The Long Farewell And Still May Sigh In Thoughts No Heart Hath Penned Alone In Loneliness Where Sorrows Dwell And Hopeless Hope, Hopes on And Meets No End Wastes Without Springs And Homes Without A Friend (Robinson LPJC 77: 1011-19)

Here the speaker sets up within his mind both a personal and symbolic 
threshold which seems destined to endure for eternity. Dark imagery controls the poem, creating a nightmarish atmosphere in the realms of his own mind. His world-view is now altered into a state of perpetual limbo where love, which is eternally imprisoned, eternally sighs "the long farewell," and death, though eternal, never enters the world of the speaker to "sound the knell." He is caught between Iife and death, despair and hope, as "hopeless hope, hopes on and meets no end."

In the final stanzas of Child Harold the forest image reemerges. The speaker, who has existed in a limbo of prolonged transition, as he sought to recapture Mary, if only in vision, metaphorically transforms the forest into his "wedded mate," but his quest ends in further transition because, at the same time, he claims:

I Laugh at Love and all its idle fate

The present hour is all my lot allows

An age of sorrow springs from lovers vows (Robinson LPJC 88: $1288-90)$

The speaker seems doubly trapped at the transition state, both wedded to the forest, yet renouncing "lovers vows." In claiming the forest as his "wedded mate" the forest itself becomes liminal, both permanent and impermanent, and reality becomes ambiguous. The speaker has returned to a position approximating the one from which he began at the opening of the poem, but the difference in tone--the transition from sighing to laughing--indicates the impact the intervening emotional experiences have had on him. His defiance "is strengthened rather than softened by its relationship to the imagery." Now, back 
in the security and solitude of the dark forest, he laughs; but as Howard points out, "the failure of the forest, and everything he has embodied in it to compensate for the loss of Mary, is implicit in his laugh" (157). He remains trapped at the threshold, both confirming and denying nature's ability to help him transcend the pain and loss caused by Mary's absence. Iikewise, his abilities as a poet have failed to bring him solace because although he has altered his perception of the landscape, the corresponding image he creates of a "wedded mate" is both a source of joy and sorrow. His poetry is unable to transport him to the desired state of union with Mary. A similar threshold is created in Keats's love poem "To Fanny" where the speaker dramatizes characteristically ambivalent judgements of his love for Fanny Brawne: a love which, the speaker claims, is the "sweet home" of all his "hopes and joys," but is also the home of all his "fears" and "panting miseries" (Cook 330: 9-10). As an uncertain transitional figure hovering between dreamer and poet, and poet and lover, the speaker literally struggles on the threshold trying to create harmony between love and poetry in his poem. Although he manages to become intensely involved in the poetic vision of his love, his feelings about love are distorted by jealousy, and pleasure becomes pain.

In "To Fanny," love is the driving force behind the speaker's poetry, but creating poetry prohibits him from becoming totally engaged with the object of his love, and he wishes only to rid himself of his overwhelming propensity for verse so he can meditate on his "dearest love" (Cook 330: 8). In the brief introduction, he invokes 
nature as "Physician" to heal his spirit, heart, and mind:

Physician Nature! let my spirit blood!

0 ease my heart of verse and let me rest;

Throw me upon thy Tripod, till the flood

Of stifling numbers ebbs from my full breast.

A Theme! a Theme! Great Nature! give a theme;

Let me begin my dream (Cook 329: 1-6)

In this passage he perceives nature as an active agent who is capable of helping him expunge the "flood of stifling numbers" which ebb from his full breast. Though the muse keeps him agitated, he longs to separate himself from his creative imagination, so he can call up the vision of his love in a waking dream. Ironically, when he enters the dream state, he becomes further isolated from his love. Iike the knight in "La Belle Dame Sans Merci," he is "alone and palely loitering," merely a spectator of a scene in which he plays no part. In the poem he is composing, he is only able to speculate on what his love may be doing at the present:

To-night, if I may guess, thy beauty wears

A smile of such delight,

As brilliant and as bright,

As when with revised, aching vassal eyes,

Lost in soft amaze, I gaze, I gaze! (Cook 330: 11-16) After he enters the "dream," his perception of Fanny becomes strongly ambiguous and undergoes a succession of transformations in which she seems to rise in his scale of values from the earthbound "sweet home" of all his "fears and hopes and joys and panting miseries" (Cook 330: 
8-9), to an elusive, ethereal image who, captivated by the enchantment of the moment, might swim through "the dance's dangerous wreath" into another's arms (cook 330: 27). He is powerless to intervene and can only plead, through his poem, that she be "a temperate lily," and as "temperate as fair" (Cook 330: 30). In the final transformation he elevates her to the sacred by describing her as his "Holy see of Love" and referring to her unviolated hymen as "the sacramental cake" (Cook 331: 51, 53). Though the speaker's attitude here prompts the reader to question the connection between the sacred and the profane (just as Keats equated the experiences of pain and loss in Hyperion with part of the poet's spiritual transformation), to the speaker, Fanny's beauty inspires the same impulse, thereby putting him in touch with another form of intensity--a vision of sacred life which is kindled by his imagination. The speaker's proposal of this divine-erotic context is substantiated in a letter Keats wrote to Fanny in which he explains:

I have been astonished that Men could die Martyrs for religion--I have shudder'd at it--I shudder no more--I could be martyr'd for my Religion--Love is my religion--I could die for that--I could die for you. My Creed is Love and you are its only tenet. (cook 519)

Within the poem, though the speaker is the creator of the love poetry, love seems to slip in and out of his grasp, and Fanny herself is a liminal object. At times, he sees Fanny as a spirit, eternally vanishing from his sight, having been transported by the music breathing "voluptuous visions into the warm [night] air" (Cook 330, 
26-27). At other times, he is jolted back to the mundane by his intense feelings of jealousy, which further distance him from his fonder thoughts of 1ove. Unlike "Ode on a Grecian Urn," where the "still unravish'd bride" depicted in the frieze suggests a metaphorical lover who is "forever warm and still to be enjoyed," though both the ode and "To Fanny" depict liminal states, the speaker's silent plea in the latter, that his love "keep that hand unravished at the least," together with her physical absence, suggests that for the speaker, only a forever unaccomplished and thus unpleasurable experience lies ahead.

In the fourth stanza his tone becomes taunting and mocking and he perceives Fanny's love as fluttering and erratic:

Why this-you'11 say--my Fanny!--is not true;

Put your soft hand upon your snowy side, Where the heart beats: confess--'tis nothing new-Must not a woman be A feather on the sea, Swayed to and fro by every wind and tide? (Cook 330: 33-40) His former ability to have positive daydreams about his love has been destroyed. He now considers her love untrustworthy, and "to know it is to despair" (Cook 330,41$)$.

The speaker's perception of his love, their love relationship, and their spatial and temporal distance in the poem are fraught with ambiguity and the successive transitions and changes multiply: from warm to cold, earthbound to ethereal, audible to inaudible, mundane to sacred, and the tone from adoring to mocking. Though, for the 
speaker, the acts of loving and creating poetry are synchronous and indivisible, paradoxically, the poem grows out of their contraries, as well as the speaker's contradicting passions of love and jealousy. In the end, his condescending attitude toward his lover thwarts his efforts to achieve fulfillment in his love for her and he becomes despondent. Though he continues to plead with her to "keep him free from torturing jealousy," (Cook 331: 48), he threatens that if he cannot have his way, may his "eyes close love on their last repose" (Cook 331: 55-56), which suggests that he feels that only death will free him of his mortal pains caused by love and poetry - Curiously, the speaker implies that death will be the great leveler of love; but since he portrays love as a metaphor for poetry, death would mean the end of poetic invention as well, though, of course, the poem would stand as testament to the poet's life and love. In either case, through the process of the poem, the speaker sets up a personal threshold (his perception of his dilemma), within a symbolic threshold, (his ambiguous ever-changing perceptions of his love), where he remains caught between the destinies of mere dreamer and true poet, love and poetry, despair and hope, and life and death.

Keats first explored man's striving to become one with his ideals in Endymion, one of his earlier works, and became preoccupied with the notion of the attainment of the ideal through love of the earthly or real--the real and ideal becoming one through intense, sensuous love. This quest is realized in "The Eve of St. Agnes" when Prophyro and Madeline consumate their love:

Beyond a mortal man impassion'd far 
At these voluptuous accents, he arose,

Ethereal, flush'd, and like a throbbing star

Seen mid the sapphire heaven's deep repose;

Into her dream he melted, as the rose

Blendeth its odour with the violet...(Cook 262,3: 316-21)

Through the intensity of their attraction to and union with each other, they achieve (or at least, Prophyro achieves) a state beyond a mortal man. Keats also believed, as in Hyperion, that the poet had the ability to transcend tragic pain and loss through the creation of beauty in poetry, and that the poet's creation of beauty is the more intense for his having felt and transcended tragic pain or the loss of faith. In Keats's love poems, the speaker becomes obsessed with the thought of woman's love, believing that her love can serve as a refuge from pain, yet, paradoxically, all the while he is experiencing pain caused by that same love. Though love is the source of his poetry, it also inhibits his poetic expression and he is unable to find a place where love and poetry can exist in harmony. Iove and poetry are both a source of intense pain and intense pleasure, yet his desire for their intensity, as well as the accompanying beauty which could be derived from such an experience become the catalyst for both needs. Though at times he opts for waking areams or hopes to achieve life through death, like the speaker in Clare's love poems, he is unable to merge the real with the ideal, and by his creation of "resolutions," which in turn, are equivocal, he reinforces the threshold from whence he began.

Whether recognized fully by the poets' conscious intelligence, 
both Clare and Keats attempt to recreate their Iives within their love poems, but the resulting "lives" are as difficult to accept as their own deaths might be. In working out their realities through poetry, they create scenarios to which they become bound and can never be freed. Rodriguez claims that for the poet, consciousness of this fact is more acute than that of any other, because whether by active choice, fate, or some mystical premium, "it is wedded to thought itself and to language itself" (225). In their attempt to draw the object of their love in closer proximity to, or into the self results in an in-turning consciousness that discovers it can no longer perceive the object in the same way, or, in Clare's case, at all. In Clare's Child Harold, the speaker is unable to make the imaginative leap whereby he could make Mary's presence felt in the landscape, and in Keats's "To Fanny," the speaker completely loses sight of his love as he once knew her because of his conflicting feelings of love and jealousy, and concludes by threatening to choose death over love, if love cannot be had on his own terms. In both instances, the speakers' memories of their loves lose all shape and definition. In Keats's poem the speaker is unable to distinguish between truth and conjecture; and in Clare's poem, the limiting lines in the landscape by which the speaker could descry and feel Mary's presence simply vanish. What is generated in both poems is "a kind of formless abyss into which the self falls in a vain attempt to repossess the object it once perceived as object" (Chilcott 244). 
CHAPTER VI

PURGATORY

In explaining the threshold states the poets create in order to "remake" reality, I referred to Clare's and Keats's speakers as being trapped in a perpetual limbo of their own making. However, on a deeper level, their situation is far more acute than merely the vague state or condition the term suggests. More aptly, their dilemmas could be equated with the state of Purgatory because both are experiencing banishment and suffering which they hope will be only temporary, as they undergo the pain and loss necessary to be made fit for paradise. Viewed in this light, the speakers in the love poems exist in what Tim Chilcott aptly terms a "no man's land of the spirit" where time, space, memory and self take on different and often larger significance as they grapple with questions regarding the intricacies of human love, the function of poetry, and the grounds for hope of immortality.

While Clare assumed the more hopeful position that man would be redeemed by God and taken to heaven, Keats felt that this consolation not only disregarded but contradicted the process by which we hourly acquire our experience. Instead, he perceived the world as a "vale of Soul-making," a "place where the heart must feel and suffer in a thousand diverse ways" in order to "school an Inteliigence and make it 
a soul" (Cook 473). Despite their different beliefs on the prospects of their own immortality, their love for the women in their lives formed such a great part of them that they were more concerned with rearrangements of the world their mind neeeded to compose in order to compensate for the tragic contrast they felt "between the extreme perfection of love and the extreme imperfection of circumstance that it is set in" (Rodriguez 204). This opposition of world and love lends to their love poems a deep and symbolic level of meaning, and in this respect, they can be construed as unresolved arguments which take the form of a "meditative dialectic" where the speakers are in a continual process of inquiry and quest (Chilcott 158).

This inquiry and quest for the essence of love are expressed in Clare's "Say What Is Love" and in Keats's "You say you love" where the speakers present a series of seemingly irreconcilable contraries. While Clare's song is built upon a relatively patterned structure of questions and answers and Keats's is built on a pattern of statement followed by qualification, in both the impetus is toward a reversal of ideas. With his thoughts of love centered on Mary, clare's speaker asks:

Say What Is Iove--To Live In Vain

To Live \& Die \& Live Again

Say What Is Iove--Is It To Be

In Prison Still \& Still Be Free

or Seem As Free--Alone \& Prove

The Hopeless Hopes of Real Love... (Robinson, LPJC 78:

1020-25) 
As Chilcott points out, what is immediately striking about this song is the capitalization of every word, indicating that the very agency of expression, language, has become problematic and is wrenched into visual disturbance on the page. As for the words themselves, no sooner is a word mentioned than it is undercut by its opposite: to Live \& Die, to be "In Prison Stil1 \& Still be Free," etc. What seems to be reflected in the verbal tensions the poem sets up is the opposition between language and feeling; that is, the words themselves are symptomatic of Clare's belief that "Language has not the power to speak what love indites / The soul lies buried in the Ink that writes" (Robinson IPJC 1015).

Keats's song "You say you love" follows a similar line of statement and undercut, but the tone is more argumentative than speculative, yet the speaker still persists in begging at the end of each stanza, "Oh Love me truly!":

You say you love; but with a voice Chaster than a nun's, who singeth

The soft vespers to herself While the chime-bell ringeth-o love me truly!

You say you love; but with a smile Cold as sunrise in September;

As you were Saint Cupid's Nun, And kept his weeks of Ember. o love me truly! (Cook 58: 1-10) What the speaker is searching for is the flame of intensity in his 
lover that will prove her undying devotion, but by his interjection of antitheses, he undermines his own conception of love as heaven's borne. In both songs, the speakers' act of verbalizing their questions about love, which was heretofore an unnamable essence, is to destroy it. The more intently they try to approach its meaning the more they come to realize the frustration and futility of their quest. By their very contrivance, the songs have undermined their purported messages and fail to communicate what was intended.

Another common aspect in Clare's and Keats's love poems is that rarely is nature viewed as a state of inviolable neutrality. Instead, its role is transitory and serves as both a "mirror and metaphor for interior crisis" (Chilcott 163). In Clare's "Written in a Thunder Storm July 15th 1841," which is included in the middle section of Child Harold, the speaker's new mood of violence introduced in this section by the Iines "Cares gather round I snap their chains in two" (Robinson, IPJC 48: 208-9). In this passage "cares" are perceived as aspects of nature which lie sharply in contrast to the speaker's present lethargy. Though "The Heavens are wrath" and "the thunders rattling peal / Rolls like a vast volcano in the sky" (IPJC 48: 217-8), the speaker claims that nothing "starts" the apathy he feels because:

My soul is apathy--a ruin vast

Time cannot clear the ruined mass away

My life is hel1--the hopeless die is cast

And manhoods prime is premature decay (Robinson, IPJC 48: $221-4)$ 
Though at first the speaker is unyielding in his indifference to the storm's violence, as the poem continues, he begins to look to the storm for it purifying properties, if not believing its energies capabie of melting his heart and soul, at least maintaining that when its energy is spent, the sun will be restored. Similar to Keats's idea of the world as a "vale of Soulmaking," the speaker seems to consider the storm a necessary annoyance earthly beings must endure, but at the same time he appears to have transcended its wrath altogether by achieving an altered state:

I live in love sun of undying light

And fathom my own heart for ways of good

In its pure atmosphere day without night

smiles on the plains the forest and the flood (Robinson, LPJC 48: 229-32)

Most striking in the poem is the speaker's perception of nature, the storm, as merely another earthly "delusion" he must overcome:

Smile on ye elements of earth \& sky

or frown in thunders as ye frown on me

Bid earth and its delusions pass away

But leave the mind as its creator free (Robinson, LPJC 48: 233-36)

The paradox of the poem is that while the speaker claims he lives "in love sun of undying 1ight," at the conclusion of the poem, the storm continues to "frown" on him. His liberation remains incomplete because he is still conscious of his self-identity; and, in Keatsian terms, his inability to exercise Negative Capability prevents him from 
experiencing his former intimacy with nature, and nature becomes a mere obstacle like sorrow or pain, that must be endured.

As illustrated in Clare's "Thunderstorm" and in all of Child Harold, the sense of space is delocalized, suggesting an emotional state rather than a geographical location. This same delocalization of space operates in Keats's ode to Fanny, "What can I do to drive away," yet at the opening of the poem, the speaker's mood is not one of apathy, but is highly agitated because the memory of his love is far too painful for his senses to bear, and he looks to his imagination to help him take visionary flight from his painful remembrance of their parting. While in Clare's "Thunderstorm" the speaker bemoans his inability to break through his despondency and regain the mental and emotional spirit he needs to enjoy his former intimacy with nature, in "What do I do to drive away," Keats's speaker is confronted with the problem of being unable to create poetry because the memory of love is sapping all his energies. Just as Clare's speaker looked to the storm as a potential cathartic agency, here the speaker seeks the redemptive powers of poetry and considers love erratic and the ultimate source of pain. Because the poem begins immediately after an ecstatic love meeting, its movement traces the speaker's journey into self, and the images described are not harmonies, but irreconcilables, with patterns flying apart. The result is the inverse of the "pleasure thermometer" which Keats outlined in Endymion, where intense feelings lead to assimilation with the desired essence; and so the result is increasingly negative intensities. In the process of his meditation on love and poetry, the 
speaker experiences an ebbing of passions which produces a poetry of pain. The intensity of the opening stanzas is reduced to violent scenes and feelings of numbness when his muse fails to respond to his need to rise above the pain of 1ove. In the course of the poem, his mood only darkens, and he allows himself to be drawn into the oppressive gloom of the landscape he describes:

That monstrous region, whose dull rivers pour, Ever from their sordid urns unto the shore, Unown'd of any weedy-haired gods; Whose winds, all zephyrless, hold scourging rods, Iced in the great lakes, to afflict mankind; Whose rank-grown forests, frosted black, and blind, Would fright a Dryad; whose harsh herbaged meads Make lean and lank the starv'd ox while he feeds; There flowers have no scent, birds no sweet song, And great unerring Nature once seems wrong (Cook 328: 33-43) As in Clare's "Thunderstorm," here nature's role is also perceived as transitive, but it seems far more threatening because of its grotesque, surrealistic depiction. Though in "Thunderstorm" the speaker is actually witnessing a storm, even though the natural surroundings, now elusive and fugitive, mirror his interior turmoil, Keats's speaker's landscape is purely a product of his imagination, so the process of delocalizing space is twice removed. However, the end result is similar, but with more intensity because the forbidding landscape is a metaphor for the speaker's own dark thoughts. His conceptions of love and poetry seem to merge and become bound in "that 
most hateful land" (Cook 328: 31). Within his own mind the speaker becomes dungeoner of himself because he willed to love, and the "shadows of this hell" are of his own making because it is the direction he chose to take in working out his dilemma as both lover and poet.

The speaker eventually emerges from the mental confusion of this stanza and moves to the other extreme as he posits his proposal for reconciling the tensions between love and poetry. In this final stanza, the "soul," which represents the speaker as poet, manages to "dissipate the shadows of this hell," by conjuring up his "lady bright" in a poetic dream:

0 , let me once more rest

My soul upon that dazzling breast!

Let once again these aching arms be placed, The tender gaolers of thy waist!

And let me feel that warm breath here and there To spread a rapture in my very hair,-0 , the sweetness of the pain! Give me those lips again! (Cook 329: 48-55)

Though love and poetry converge in the poem he creates as he dreams of his "soul" resting upon his love's dazzling breast," the tensions remain unresolved because in Iife, he is bound to mortality where the sensuous essence of love is mingled with "the sweetness of the pain," and the poem alone stands as a symbol of the reconciliation of these forces. Though he manages to create a waking dream to ease his pain, for him as well as the speaker in "Thunderstorm," liberation is a 
desired rather than an achieved state because he too was unable to move beyond the consciousness of self-identity.

The changing views of nature depicted in these passages illuminate both the dialectic spirit of the love poems as a whole and the transitive function of natural objects, but more importantly, in the love poems, awareness of self takes on a larger significance than in any of their other poetry. As Chilcott points out, there are three different contexts in which that awareness is located: "the 'I' placed in a world of absence and deprivation, the ' $I$ ' caught in an ambiguous realm of both freedom and imprisonment, storm and calm, and the 'I' transfigured into a beatific vision of love and eternity" (168). Though this phrasing may suggest a movement from loss to transcendence, these contexts of the self are not progressive steps in a process of enlightenment, but are more similar to Keats's comparing human life to a "Mansion of Many Apartments." Though the different contexts can be experienced and explored, they constitute three aspects of debate which are never resolved in the poems. As a result, interpreting the meaning of the poems lies not only in symbol or situation, but also in the direction the speakers take in attempting to work out their dilemas, and this "direction" is always dependent on the degree to which they are able to move beyond self to a casual disinterestedness.

An important aspect of the first context where the "I" is caught in a world of absence and deprivation is that the resulting dissociation of the speaker from the object of his love does not allow him to realize his identity more fully or even more clearly, but has a 
dulling effect in which "I" loses all defining personality and becomes numbed and anonymous. For example, in Keats's "What do I do to drive away," the speaker's self-identity becomes confusedly mingled in the turmoil of the "most hateful land" he conjures up, yet the tone of the stanza is the most subdued of all the stanzas in the poem because his passion has diminished to a state of lethargy. Rather than being able to create selfless poetry about love, his poetry reflects only a drowsy numbness of the senses. His zest for the natural world he recalled at the opening of the poem, when he was in his "old Iiberty" (Cook 327: 6), has vanished and his emotional attitude toward nature, love, and poetry are less certain, verging on extinction. In the poem, this absence of relationship is indicated by the eventual numbing of the speaker's senses: "Flowers have no scent, birds no sweet song," and by metaphorical extention, his poem is a reflection of this woe (Cook 328: 42).

The speaker in Clare's Child Harold also experiences a similar dissociation and is portrayed as deprived of his relationship with nature--the touchstone for all his memories of love and youth. In the process, the speaker also loses sight of his personal identity:

Dull must that being live who sees unmoved The scenes and objects that his childhood knew The school yard and the maid he early loved The sunny wall where long the old Elms grew Beneath the wallnut shade I see them still Though not such fancys do I now pursue Yet still the picture turns my bosom chill 
And leaves a void--nor love nor hope may fill (Robinson, LPJC 62: 603-11)

He refers to himself only as "that being," and describes himself as "dull" and "unmoved." Though he gazes on a familiar landscape, it contains for him only foreign objects, which "turn [his] bosom chill" and leave a tremendous void that ultimately nothing, not even love or hope, can fill.

As opposed to this image of "deadened self," the love poems of Clare and Keats often emphasize a self-consciousness trapped within an ambiguous realm of changing values. As evidenced in Clare's "Thunderstorm" and Keats's "What can I do to drive away," absence can also cause intensity of feelings, resulting in the speakers' creation of ambiguous realms of both freedom and imprisonment. Though in "Thunderstorm" the speaker finds intensity living in "love sun of undying light" (LPJC 48: 229), he accomplishes this same type of spiritual transcendence in the absence of Mary, where he fills the void with his, at times, unyielding love for her:

I can forget thee never

While the meadow grass is green

While the flood rolls down the river

Thou art still my bonny queen (Robinson, LPJC 73: 914-17)

While at other times, liberation is achieved through a "passive immersion in a mirroring solitude" (Chilcott 171):

In this cold world without a hame

Disconsolate I go

The summer looks as cold to me 
As winters frost and snow

Though winters scenes are dull and drear

A colder lot I prove

No home had I through all the year

But Marys honest love (Robinson, IPJC 74: 933-41)

In contrast to Keats's speaker in "What do I do to drive away," who finds liberation through transcendence in a waking dream, Clare's speaker realizes identity both within a "frozen self" and within Mary's "honest 1ove;" but the paradoxical nature of the "world" he constructs is heightened by his use of the past tense. Though his union with Mary is established with his mention of her in the poem as his "home" through "all the year," the fact that he can only speak of her in relation to past events reaffirms his resignation to his solitary confinement in a world without Mary, even though the mention of her name creates for him a liberating effect.

Important in discussing the first two contexts in which the speakers' awareness of self is located (a world of absence and deprivation, and a realm of both freedom and imprisonment), is the role of memory, the only means by which they can effect reunion with the past. Through memory they are able to escape the present and "miraculously" retrieve the past, but the very fact that the retrieval of the past results in such an aching presentness suggests that sometimes memory may surface as much by its own agency as by any willed act on the part of the speakers. In this respect, memory creates a haunting effect wherein the speakers become possessed of a vacancy by which, in turn, they become dispossessed. In Wordsworthian 
terms, to reconstitute the past is to acknowledge that what has gone before was the experience of same other "Being" than the present self. The realization that temporal awareness draws into focus the conflicts between the past and present often results in loss of self, rather than self-validation. To combat this problem, sometimes the speakers seek redemption through a heavenly vision, believing it the only means of staying their seemingly inevitable fall into nothingness. In this third context of awareness, the "I" is transfigured in a beatific vision of love and eternity wherein the self undergoes, by degrees, a release from the burden of subjectivity. In the middle section of Child Harold, Clare's speaker experiences such a release by categorically attributing love as a gift from God:

Gods gift is love and do I wrong the giver

To place affections wrong from Gods decree

--No when farewel1 upon my lips did quiver

And all seemed lost--I loved her more than ever (Robinson, LPJC 50: 296-99)

By perceiving his love and devotion to Mary as a duteous response to "God's decree," he finds empowerment and meaning in this seemingly hopeless task, as well as a reason to continue loving despite all his reservations and doubts, concluding that "Twas heavens own choice--and so Gods will be done" (IPJC 51: 302). The speaker's release from self occurs slowly and by degrees. The two stanzas are written in the form of a soliloquy, and references to Mary are all in the past tense: "I loved her in all climes beneath the sun" (LPJC 300), "Her name was like a jewel in my heart" (LPJC 301), and "Mary filled my arms" (IPJC 
308); but in the "Song" that immediately follows, he manages to break through the barriers of self and commune personally with Mary:

O Mary sing thy songs to me

of love and beautys melody

My sorrows sink beneath distress

My deepest griefs ar sorrowless

So used to glooms and cares am I

My fearless troubles seem as joy

O Mary sing thy songs to me

of love and beautys melody (Robinson, LPJC 51: 309-16)

Here the transcendence is complete. Though it could be argued that Mary is still absent and the speaker is still suffering from the pain of that 1oss, what emerges in this song is the speaker's heightened perception of his situation. He views the pain of love not as a mortal burden, but as a gift of the divine which, because he believes this is so, enables him to negate, or at least to neutralize, all of love's adverse effects. His "sorrows sink beneath distress," his "deepest griefs" become "sorrowless," and "fearless troubles seem as joy." In a sense he has been numbed by the constant barrage of pain he has been experiencing; but he has been numbed into "joy" rather than into a state of "deadened self" as seen elsewhere in Child Harold. What he has garnered from his meditation on the source of love, and consequently deeming it of divine origin, is an absolute faith in its existence and a confidence that it dwells in the realm of immortality. In the conclusion of the song he expresses the relief this epiphany has allowed him. Confident that Mary's love exists 
unequivocally, he can now fearlessly consider "what is not" and validate "what is":

But heaven itself without thy face

To me would be no resting place

And though the world was one delight

No joy would live but in thy sight

The soul of woman is my shrine

Then Mary make those songs divine

For music love and melody

Breath all of thee and only thee (Robinson, LPJC 51-2:

$325-32)$

In the process of arriving at a beatific vision of love and eternity, the speaker also effects a harmonious fusion of love and poetry. This vision, completelty devoid of any "mortal bars" to its fruition, is (with the exception of the stanzas on Autum, discussed in the following chapter) the only occurrence of such a pure convergence of love and poetry in the entirety of Child Harold. But the pain of love is still to be endured, though he has managed to assimilate it along with the pleasures of love so that "fearless troubles seems as joy," similar to Keats's speaker's acceptance of the "sweetness of the pain" in "What do I do to drive away." And, it cannot be overly stressed that this particular context of the location of self in a state of "selflessness" is not an achievement of any finality. Instead, the speaker reverts from one state to another throughout the poem, and the poem concludes with no apparent resolution and the theme of purgatory pervades. 
This same erratic movement can be traced throughout Keats's love poems to Fanny Brawne, where the context of self continually shifts, and the speaker only attempts, but never arrives at such a feeling of unconditional love as depicted in the passages discussed above from Child Harold. But of all Keats's love poems, the speaker in "Bright Star" comes closest in realizing a beatific vision of love and eternity because he at least manages a glimpse at the possibilities of being immortal. The tenor of "Bright Star" moves in a similar direction as Keats's other love poems, with the speaker involved in a symbolic debate which follows the process of assertion, withdrawal, qualification, and partial return, but his mood remains speculative and subdued throughout, and he comes away from the experience with greater knowledge, because he does not succumb to pain, anger, or jealousy, or resort to mere fancy in attempting to improve his situation.

At the opening of "Bright Star," as the speaker gazes at the vast panorama of the heavens towering above the dark sea, he spies one lone star hanging in "splendor," a sight that fills him with the desire to be as "steadfast" as the star:

Bright Star, would I were stedfast as thou art--

Not in lone splendor hung aloft the night, And watching, with eternal lids apart, Like nature's patient, sleepless eremite, The moving waters at their priestlike task of pure ablution round earth's human shores, or gazing on the new soft-fallen masque 
of snow upon the mountains and the moors--

No--yet still steadfast, still unchangeable

Pillow'd upon my fair love's ripening breast,

To feel for ever its soft swell and fall,

Awake for ever in a sweet unrest,

Still, still to hear her tender-taken breath,

And so live ever--or else swoon to death--(Cook 325: 1-14)

As Bate points out, the star is perceived as a metaphor not only of permanence but of a 'disinterestedness' and fundamental order and repose which inspires in the speaker a vision of sacred life, with beauty serving as the basis of all truth. He looks to the star as a symbol of divinity, and by juxtaposing this vision with the vision of his love, he fuses the divine with the very human sexual reality of 1ove. His use of the term "eremite" infers the spiritual role of the poet as officiating over the domain of his love in a ceremonial priestly manner. Though this office demands a certain amount of detachment which would seem to answer to the poet's desire of achieving a state of selflessness, it proves inadequate because his most profound desire is to enjoy qualities of permanence and detachment that are denied to mortal men. He longs for the steadfastness of the star, but not its lone splendor; he wishes for unchangeableness, but without relinquishing the intensity of human passion. He explicitly longs for love and poetry to coalesce, but realizes that only by achieving immortality could this become possible. Thus, the relationship the speaker sets up between himself and his beloved involves his living both in and out of time. He does 
not want to feel caught between the "lone splendor" of the star and his "love's ripening breast," so he chooses to have both. As Rodriguez points out:

The relation, Keats and Beloved, has its own order of creative presence and time: it is unchangeable yet forever beating like a heart in a "sweet unrest." In a consciousness that feels the convergence of beauty and truth, it is no wonder that the immediacy of lover and beloved is likewise sacred, at once physical and spiritual, sensuous and holy as in the "warm" love of "Ode to Psyche." (203)

For a fleeting moment within the world of the poem the speaker effects a spiritual transformation wherein a vision of sacred iffe is touched and savored by his poetic imagination, yet because he is intrinsically bound to the framework of mortal experience, he concludes by reminding himself of the possibility that death is final, though if he died from love's intensity, that appears to be a pleasing outcome for the speaker.

In "Bright Star" and the selected passages from Child Harold, both Keats's and Clare's speakers undergo a spiritual transformation of sorts, wherein they recognize the divine nature of love, and hence its immortal nature, and achieve--if only temporarily--a harmonious union between love and poetry. Though they are still in an emotional "Purgatory" at the conclusion of their verse, they have glimpsed eternity; and in the creation of their poetry, the "life of the heart" has been made "tangible and holy" (Rodriguez 200). 


\section{CHAPTER VII}

\section{PARADISE}

As discussed in the previous chapter, the speaker in clare's Child Harold and in Keats's "Bright Star" attained an emotional plateau through engagement with higher knowledge. From the experience, they gained the awareness that love is an emanation of the divine, both sacred and immortal, and this knowledge gave rise to their essential or formal recognition of Paradise, wherein memory and imagination were momentarily divorced from their immediate circumstances. No longer afflicted by feelings of pain, sorrow, and Ioss they associated with love, and no longer questioning their need to be there, at the center of devotion to an "other," they allowed their desires to be realized in their hearts, and succeeded in creating a poetry of harmony where love and poetry, and beauty and truth might be embraced and nurtured. Though pain and doubt were only briefly suspended, they managed a glimpse of Paradise.

While these are notable high points in the love poems of Clare and Keats, they achieved the fullest sense of resolution in their poems depicting their emotional response to Autumn. Clare's stanzas and songs on Autumn serve as the structural center of Child Harold and are high point of Clare's emotional quest, the only moment he experiences pure joy. Though Keats's ode "To Autumn" was not written 
expressly for Fanny Brawne, it is important in the context of the love poems as a whole because it was written during the same period of his Iife as the love poems, the fall of 1819; and similar to clare, it is in "To Autumn" that he achieves a successful union of the ideal--of the heart's desire--and reality, a union he continually strives for in the love poems. Both Clare's and Keats's Autumn poems are poems of acceptance; there is no striving to reconcile contraries. Instead, the poets themselves become lost in their images, and the images are portrayed as they actually are, not as representations of other wished-for "realities." A noticeable difference in their impressions of natural objects in these verses is that clare continues to equate nature with Mary, whereas Keats is able to isolate his enjoyment of Autumn from all other personal experiences. However, both achieve an intensity of experience not seen in the other poems discussed in this study because they are able to repress contraries that would interrupt the prevailing tranquility. As Chilcott points out, in the love poems the speakers' act of creating poetry about their love is not an extention of their experience, but a confrontation with it. In this respect, language does not continue reality, but interrupts it. Though literalness is at times displaced by metaphor as the autumn landscape is described in these poems, the new reference is not remote or fictive, but helps to delineate the pure essence of the season. The stability of Clare's and Keats's verses on Autumn derives both from the remarkable control and poise they demonstrate, as well as from the peculiar harmony their landscapes evoke, rendering what Bate describes as a sense of a genuine paradise of prolonged 
fulfiliment through the resolutions the poems effect. In both cases, resolution is partly attained by "a union of process and stasis" (Bate 582). Clare's first stanza begins in stillness:

Sweet comes the misty mornings in September

Among the dewy paths how sweet to stray

Greensward or stubbles as I well remember

I once have done--the mist curls thick and grey

As cottage smoke--like net work on the sprey

Or seeded grass the cobweb draperies run

Beaded with pearls of dew at early day

And oer the pleachy stubbles peeps the sun

The lamp of day when that of night is done (Robinson, LPJC $65: 696-713)$

Though mist, smoke, and dew veil the landscape, the speaker's vision is not blurred as often occurs elsewhere in Child Harold, nor does he attempt to transform what he sees into an abstraction. In contrast, there is a luminous quality evinced here, with each detail gradually advancing into focus. For the speaker, the act of seeing is an act of recognition, the confirmation of real objects within a familiar environment. This confirmation is substantiated when he emphasizes "as I well remember I once have done," validating both the past and the present. Subsequent stanzas continue to portray the speaker's pleasure with Autumn. After the sun rises and the day unfolds, amid the "strong glances" of the noonday sun, the speaker's tendency is not to transform, but to perceive the countryside as a veritable Eden (IPJC 65: 706). Though the "homesteads very grass seems changed to 
gold," and "the light in golden shadows seems to run / And tinges every spray its rests upon" (my emphasis), his fancy is counterbalanced by actual occurrences in real time as "the hare starts up before the shepherd boy / And partridge coveys wir on russet wings of joy" (LPJC 65: 707-10). Though there is a hint that the end of autumn is inevitable, and that the "foamy floods" of winter will "spread a restless ocean foaming wide" across the meadow, in the first three stanzas stillness prevails, and for now, "the cowboys sleep nor fear the coming tide" (IPJC 66: 719-21).

The fourth stanza maps the process of Autumn, but its fulfiliment, as well as that of the speaker, is prolonged by the continuous presentness the scene conveys:

About the medows now I love to sit

on banks bridge walls and rails as when a boy

To see old trees bend oer the flaggy pit

With huge roots bare that time does not destroy

Where sits the angler at his days employ

And there ivy leaves the bank to climb

The tree--and now how sweet to weary joy

--Aye nothing seems so happy and sublime

As sabbath bells and their delightfull chime (Robinson, LPJC $66: 723-31)$

As a whole, Clare's stanzas on Autumn deplct a landscape untainted by any thought of death: "sloe and dewberry shine along the bank," "weeds in blooms luxuriance lately grew," and "Nature life's sweet companion" continues to cheer (IPJC 66: 715-16, 711). Moreover, the landscape is 
enhanced by the speaker's memories of childhood which occurred in the same location, thus uniting past and present pleasure. After the speaker becomes aware of the chiming of the village bells, the culmination of his emotional experience occurs, and the ultimate source of his joy is revealed:

Sweet solitude thou partner of my life

Thou balm of hope and every pressing care

Thou soothing silence oer the noise of strife

These meadow flats and trees--the autumn air

Mellows my heart to harmony--I bear

Iifes burthen happily--these fenny dells

Seem Eden in this sabbath rest from care

My heart with loves first early memory swells

To hear the music of those village bells (Robinson, LPJC 66: $733-40)$

For the moment, he exudes happiness and confidence because Mary is united in his mind with nature, and the truth he has sought throughout the poem has been realized. Mary was "natures self" and is still his "song" and the "truth" of his heart. This final stanza enacts a consurmation of sorts, wherein love, poetry, and nature metaphorically converge, and the truth of the heart is confirmed. Important in effecting the speaker's total communion with nature is his invocation of "Sweet Solitude" because in this state of quiet passivity (as discussed in Chapter III), Clare managed to write some of his best verse, unhampered by subjectivity and rational assessment. (However, many of his asylum poems are superlative because of their highly 
subjective nature.) Even in this section of Child Harold, the fragility of the speaker's ecstasy is apparent. It is inevitable that winter will come and "spread a restless ocean" across the meadow; it is inevitable that the speaker's emotional odyssey, now at an all-time high, will plummet with the return of his self-awareness.

In contrast with Clare's stanzas on Autumn, the importance of Keats's ode "To Autumn" lies not merely in the "degree of resolution" the speaker achieves, but that "so many different resolutions are attained" (Bate 481). Like Clare's verse, the poem presents a series of stanzas characterized by process and stasis. Though there is a sense of expectancy on the part of the speaker--of waiting with Autumn--Bate remarks that Keats manages to capture the ideal of energy caught in repose, thus achieving the aspired resolution where the past and future are simultaneously incorporated in the speaker's perception of the present. Most important, fulfillment in the poem is effected because there is no hint of subjectivity. Other than depicting the scene before him, the speaker remains emotionally uninvolved, merely allowing the serenity of the scene to wash over him. And as in Clare's verse, the images the speaker describes are entirely concrete. Though Autumn is depicted as a deity, it is described with purely natural associations. The end result is not abstraction, but intensification of the immediate scene:

Season of mists and mellow fruitfulness, Close bosom-friend of the maturing sun; Conspiring with him how to load and bless With fruit the vines that round the thatch-eves run; 
To bend with apples the moss'd cottage-trees, And fill all fruit with ripeness to the core;

To swell the gourd, and plump the hazel shell

With a sweet kernel; to set budding more, And still more, later flowers for the bees, Until they think warm days will never cease, For Summer has o'er-brimm'd their clanmy cells (Cook 324: 1-11).

In comparing the poems, the context of audience is of particular importance in the way in which the different speakers convey the scenes before them. For Clare's speaker, the experience is a personal process of "re-vision." There is no intended audience; the scene is of relevance to him and him alone. As the mist and smoke lift and the sun's rays warm the earth, he gradually draws the landscape into clearer focus, intimating that his is a highly personal recognition, thus intensifying both the concreteness and the particularity of the sights and sounds around him. In contrast, Keats's speaker presents a universal picture of Autumn where the process, repeated year after year, is familiar to all, thus inviting the reader to participate in the same fullness and intensity the scene evokes for him. The drawing in of the reader is further emphasized by his confidence when he questions: "Who hath not seen thee oft amid thy store?" (Cook 324: 12). While Keats's love poems were testimony to the speaker's sense of isolation, here he is enjoying communion with nature amid the aura of the brotherhood of man; whereas Clare's speaker remains isolated, though this is negated by his total immersion in nature. 
In "To Autumn," as evidenced by the "muscularity" of the descriptive words alone--"to load and bless with fruit," "to bend with apples," and "fill all fruit," "to swell the gourd" and "plump the hazel shells"--the title of the ode could be interpreted as Keats's coining of a new infinitive, "to autumn" (Serdar 3). The overall effect of the "fruitful burgeoning" reflected in the language is the creation of a continuous present where process is unrelenting; yet its effect is negated by stasis. Though the fruits of the season are on the verge of ripeness and fullness, Autumn continues to spur on the Growth by conspiring with the sun to "set budding more, and still more." As the speaker savors the landscape, he becomes more and more absorbed into the scene, and both process and stasis are perceived as equally satisfying, because although the loading and blessing continues, absolutely nothing in the landscape undergoes any modification whatsoever. Even the "last oozings" ooze on "hours by hours" (Cook 324:23). Though there is no completion, as occurs in Clare's stanzas on Autumn, there is a sense of fragile beauty about the landscape, intimating that the end is approaching. Sometimes Autumn "sits careless on a granary floor," or "Drows'd with the fume of poppies," and the speaker infers that these are the "last oozings" of the season.

The speaker's perception of the real world in Keats's "To Autumn" is reminiscent of Clare's earlier descriptive poetry, in that knowing natural things in their purest state is neither a goal nor a passing state of heightened awareness as they are in many of Keats's other odes where the discovery is not lasting and the speaker is drawn back 
into the subjective musings of the solitary self. Nor do the sights and sounds of Autumn startle by their newness or threaten the imagination, because the speaker is merely responding to a common awareness, existing in the here and now, yet making it a permanent condition in the world of the poem.

In Clare's stanzas on Autumn the speaker's mode of perception is a blend of meditating on the pure untranscended presence of the object (nature), while unconsciously searching the physical landscape for a stable predicate (Mary). While the conscious searching for Mary is evidencea in most of Child Harold, in these stanzas, as in Keats's "To Autumn," resolution is effortless. What contributes to both speakers' quiet enjoyment of Autumn is the solitude that "enables them to feel a sense of reciprocal communion with nature," allowing their imaginations to revel in the impressions provided by the sights and sounds around them (Howard 173). Clare's speaker's harmony gradually encompasses the village bells, which unite Mary in his mind with nature, while Keats's speaker's harmony is enriched by the music of nature alone:

Where are the songs of Spring? Ay, where are they? Think not of them, thou has thy music too,-While barred clouds bloam the soft-dying day, And touch the stubble-plains with rosy hue; Then in a wailful choir the small gnats mourn Among the river sallows, borme aloft or sinking as the light wind lives or dies; 
Hedge-crickets sing; and now with treble soft The red-breast whistles from a garden-croft;

And gathering swallows twitter in the skies. (Cook 325: 23-33)

Both Clare's and Keats's speakers' methods of perception in their verse on Autumn represent a break with the traditional means of seeking solace they exercised in the love poems. They achieve a state of selflessness in which objects that colonize the landscape are perceived as an entirety. There are no gaps or blankness, no threat of feeling personally isolated; therefore they feel no need to consciously interpret or reconstruct what they see. In contrast to the love poems where the attempt the draw the object close to the self results in an in-turning consciousness that realizes it can no longer perceive the desired object, the movement here is upward and outward to the external world, and, as Chilcott observes, it is the pure untranscended presence of the object that confers value. Though the village bells inspire Clare's speaker with the "knowledge" of Mary's presence, it is accepted as a natural phenomenon that is "known because there in no possibility that it could ever not be thus known" (Chilcott 224). For both speakers, the world of flux, both emotional and physical, is momentarily arrested and externalized in the natural cycle, and they are free to abandon themselves to its joys, thus attaining Paradise. 
CHAPTER VIII

THE IOVE POEMS OF CLARE AND KEATS: THE WIDER CONTEXT

Though neither Clare nor Keats professed a set philosophy or cosmology as did Blake, Wordsworth, Coleridge, and Shelley, they successfully managed to dramatize their personal beliefs about life, and particularly love, in the poetry they wrote to the women who had won their hearts' affections. What should impress readers about the love poems is not some image or picture of "the real John Clare" or "the real John Keats," but the meaning and usefulness of their poetics. The poems reveal simultaneously, through their skillful use of metaphor and figurative language, both the real world and the ideal world that shines behind any physical disclosure" (Rodriguez 226). In contrast to other Romantic poems of self-assessment in which the speakers arrive at a comprehensive world view from the process of personal introspection, Clare's and Keats's love poems end in paradox. In the place of the certainty reflected in the poetry of Blake, Wordsworth, or Coleridge, the love poems offer only an unremitting exposure of the problem. No other Romantic poems present such an "intricate revelation of man trying to justify the apparent conflict between his subjective response to, and rational assessment of human existence" (Howard 183-4). What both speakers face in the love poems is the characteristically Romantic fear that estrangement from the 
desired object is a fall from Eden; and in all the love poems, there is a moving search by the speakers to reclaim the object, and to perceive it as more than merely a reflection of their own self-awareness.

In the last three chapters, I have traced the speakers movement in the poems through periods of emotional hell, limbo, purgatory, and paradise, as they create personal thresholds or undergo various states of self-awareness, with the imaginative constructions of these differing states of perception significantly affecting their personal experiences. In most instances, awareness of self is an obstacle and true Paradise is only achieved by transcending the self entirely, which they accomplish only in their poetry on the subject of Autumn. Their movement through these different emotional states is not a progression, but rather a result of the extent to which they are able to engage in what Keats referred to as Negative Capability. Though the attainment of Paradise is momentary for both speakers, their very achievement can be attributed to their poetic genius, which allows them to acquire a new sense of self-discovery by objecifying their ideals.

Clare's stanzas on autumn in Child Harold and Keats's ode "To Autumn" are perfect examples of the speakers' exercise of Negative Capability. The serenity in the poems is accomplished because the speakers finally transcend their inner turmoil. Keats's ode embodies an act of resignation and an openess to the process of nature's fruition and decay, and the fact that the speaker does not extend the idea from the life of nature to the life of man further illuminates 
his immersion in exuberant sensations of the moment. There is no reaching after fact, no need for resolution. In Clare's Child Harold, the culmination of emotional experience for the speaker is when he manages to unite Mary with nature in his mind. He also experiences pure joy, uncomplicated by rational assessment.

As Bate suggests, at the heart of the speakers' accomplishment is their ability as poets to engage in "objective idealism" by allowing the mind to contribute to direct perception of the material world by supplementing, channeling, and even creating. Yet the end result is not pure imvention, something read into nature that is not really there. Instead, the product is a result of the creative mind conspiring with nature, and its insights are validated by achieving the reconciliation or union of man and nature, thus arriving at a higher truth. Yet Clare's and Keats's speakers seldom achieve such emotional plateaus in the love poems, and the conclusion of Keats's last poem to Fanny Brawne and Clare's final stanza of Child Harold reveal how elusive the state of Paradise actually is.

In Keats's poem "To Fanny," the speaker is once again plagued by pain and doubt, and tortured by jealousy. In this frame of mind he threatens:

Iet none else touch the just new-budded flower;

If not--may my eyes close

Love on their last repose! (Cook 331: 54-6) Though he toys with the idea of death as an eternal escape from the "severe" and "many" pains of love, he seems at a loss to effect any resolution whatsoever. Similarly, Clare's speaker leaves us with an 
evocation of contrasting moods rather than a concluding statement. He begins in tranquility, remarking that "Sweet is the song of Birds for that restores / The soul to harmony the mind to love" (LPJC 88: 1292), but concludes that:

Pierced hearts left burning in the doubts of love

Are desolate where crowds and citys dwel1--

The splendid palace seem the gates of hell (Robinson, LPJC

$88: 1298-1300)$

The "splendid palace," the forest, where the speaker begins at the opening of Child Harold and which he once referred to as his "wedded mate," is now perceived as "the gates of hell." For both speakers "the very act of remembrance is an act of separation," severing all links between blissful love and present awareness. And so the movement downward and inward continues, as the speakers return to a state of $1 \mathrm{imbo}$, and the self falls in a vain attempt to repossess the object it once perceived as object.

The pain expressed in Clare's and Keats's love poems is a result of the speakers' awareness that they are doomed, so each thought and feeling further traps them in the constricted space of being both poet and lover. Though in poetry they attempt to project the self into the essence of love and to realize love in earthly terms, but devoid of the inevitable pain that comes with being mortal, their attempts are often futile. Although ideally, poetry should provide a true happiness, a perfect union with love but without mortal heartache, their attempts to reconcile love and poetry go awry. And poetry, which should make love approachable and one with the self, does not 
function as it should. Consequently, as the speakers move toward resolution, the patterns of their thoughts implode and disintegrate, and their perceptions of love and poetry, their beliefs about life and death, mortality and immortality alternate between optimism and despair.

In real life, the poets themselves were also doomed. Keats knew that he and Fanny were destined to part because of his terminal illness. Clare was confined to the asylum, aware that Mary had died years before. So, in fact, they used poetry as a means of dealing with their lives, which were tortured with sickness, 1ove, anger, despair and misunderstanding. At the time they composed the love poems, both were obsessed with time--Clare because he saw his life stretching on in a never-ending path, while for Keats, there was very little time remaining. Clare remarked that he wrote Child Harold "merely to pass the time away," but nothing seemed "to shorten it in the least." He feared that he would not "be able to wear it away," and felt that "nature seem[ed] dead and her very pulse seem[ed] frozen to an iceicle in the summer sun" (Robinson, SPJC 3). In contrast, because of his quickly deteriorating physical health, Keats claimed that his "whole mind $\&$ heart were in a whirl of contending passions," he could see nothing calmly and dispassionately, and often turned to Fanny with a desperation that at times startled her. At other times he would try to arm her against his death which he termed "the uncompromising morning" of [his] life."

Particularly with regard to Keats, the value of his poetic achievement in the love poems has been discounted because they so 
clearly reflect the desperation he was experiencing at the time. While his poems are considered "painful outcries," Clare's are considered the rantings of a madman, a criticism based not on the poems themselves but merely on the fact that he was confined to an asylum when he wrote them. Yet what many critics overlook is how organized, cunning, and developed their love poems are, and thus deserving of the same kind of critical response given to their other work. The very fact that these poems serve as commentary on the poets' lives as actual human beings is in itself a testament to the level of artistry they achieved, because the feelings and ideas they express are highly personal and highly complex. In essence, the poems are intricate rearrangements of the world their minds needed to compose in order to combat the difficulties of living, of loving, and of creating poetry.

Though often poetry is characterized by the speakers in the love poems as an "enemy" to their condition, poetry never failed or abandoned them, as Keats so aptly expressed in a letter to his friend Brown:

Yet I ride the little horse,--and, at my worst, even in Quarantine, summoned up more puns, in a sort of desperation, in one week than in any year of my life. There is one thought enough to kill me--I have been well, healthy, alert $\& c$, walking with her--and now--the knowledge of contrast, feeling for light and shade, all that information...necessary for a poem are great enemies to the recovery of the stomach. (Cook 542) 
The ambition, the desire to be a poet, was uppermost in both Clare's and Keats's minds. As Clare wrote to his patron, Eliza Emmerson: "All I wish now is to stand upon my own bottom as a poet without any apology as to want of education or any thing else..." (Robinson, EPJC 1). And Howard remarks that clare would have approved of the now infamous words of the doctor at the Northampton asylum, who committed Clare with the prognosis that he was suffering from years spent "addicted to Poetical prosing" (ii). But, humor aside, as Roy Porter points out in John Clare in Context (a new collection of essays released in July of 194), "ninteenth-century doctors had genuine reservations about the wisdom of prying too energetically into patients' mental states, especially introspective and depressive characteristics" (Motion 6). In light of this, perhaps we should exercise the same caution and revise our sense of the "context" in which both Clare and Keats ended their writing careers; for, after all, it is clear that we know very little about their inner lives. Rather than judge the love poems as merely the rantings of poets who had lost control of their destinies, it is better to let them stand on their own as the living proof of Clare's and Keats's undying love. And since their love formed such a great part of them, it would be doing them, as well as ourselves, an injustice to ignore their value. Andrew Motion, the reviewer of the new critical edition on Clare, claims that the most valuable lesson the book teaches is that "in Clare we are offered alternative kinds of excellence from those we usually associate with major poets in the established canon." He suggests that rather than dwelling on the same works which have been 
studied again and again, such as "The Nightingale's Nest," "The Progress of Rhyme," "The Mores," "The Snipe," "The Flitting," "Remembrances," "I Am," and certain sections from The Shepherd's Calendar--all of which are considered "crucial,"--more discussion should be devoted to those areas of his work that are still neglected, such as Child Harold, Don Juan, and The Midsummer Cushion (Motion 6). With regard to Motion's suggestion, I hope that this study has helped to shed light on same of the many striking features of Child Harold.

In exploring Clare's and Keats's love poems, it was surprising to discover the similarities in their method of creating poetry. Though their poetic processes differ, they converge with respect to expressing feelings of love, pain, and isolation. Though they disagreed about the ways of looking at images in nature--Keats felt that Clare "overlaid and stifled what should be the 'prevailing idea; " Clare thought that Keats's descriptions of nature were overly tinged by his "fancies"--but between them lies an agreement about ways of feeling. Though they never actually met, what the two poets recognized in each other was a similar feeling of exclusion. In fact, Motion claims that being outsiders was the true ground of their acquaintance. Of course, credit is due to Keats for inventing the concepts of Negative Capability, Soul-making, and the Mansion of many Apartments, but Clare's love poems reflect similar points of view regarding the world of experience. Further comparative studies of Clare's and Keats's poetry could be applied to the context of how they perceive "Woman" in general in their poetry, a comparison of the musical qualities of their lyrics, or a study of their poetry in 
conjunction with their letters.

Both Clare and Keats tried to make a world out of all they had to work with; and what they teach us, in the late twentieth century, is that all we really have or possess is ourselves--what we know and what we feel and how we interpret experience. As they have shown, all that is important is maintaining faith in our ability to love, and taking care that the intellect does not become divorced from the heart. From our point in time, we have seen the continual separation of the two, resulting in famine, war, and destruction, not to mention racism and general intolerance. More concern should be given to the outcomes of the victims of such unnecessary tragedies. Diane Ackerman, a poet-naturalist and author of A Natural History of Love, asserts that many victims of extreme trauma, such as the drought in Rwanda, the genocide in Rumania, and the many untoward complexities of the war in Bosnia may very well become unable to love. She cites, as case in point, an entire culture, the $I k$ (a tribe of hunters and gatherers in Uganda), who, after enduring three generations of drought and starvation, actually disposed of love: "Love was not economical; they could not afford to have it," cites Ackerman; "self-interest was the only survival technique" (Atkins 19). Though this provokes a lot of questions--if love can be discarded does that mean it is purely a luxury? Is love not an essential part of our make-up? It seems that Clare and Keats knew all along the fallacy of these misgivings. I agree with Rodriguez that their love poems are evidence of genuine spiritual work of the kind our world today is sorely lacking. Though sometimes they felt that language failed to express their innermost 
feelings, they never lost sight of their firm belief in the healing power of love. This is the value of their love poems. 
SELECTED BIBLIOGRAPHY

\section{Primary Sources}

Cook, Elizabeth, Ed. The Oxford Authors' John Keats: A Critical Edition of the Major Works. Oxford: Oxford University Press, 1990.

Gi11, Stephen, Ed. The Oxford Authors William Wordsworth. Oxford: Oxford University Press, 1984.

Jackson, H. J., Ed. The Oxford Authors Samuel Taylor Coleridge,

Oxford: Oxford University Press, 1985.

Robinson, Eric and David Powell, Eds. The Early Poems of John Clare 1804-1822. 2 vols. Oxford: Clarendon Press, 1989.

---. The Later Poems of John Clare 1837-1864. 2 vols. Oxford: Clarendon Press, 1984.

Robinson, Eric and Geoffrey Sumerfield, Eds. Selected Poems and Prose of John Clare. Iondon: Oxford University Press, 1967. Tibble, J.W. Ed. The Poems of John Clare. 2 vols. Iondon: J. M. Dent \& Sons, Ltd., 1935.

Tibble, J.W. and Anne Tibble, Eds. The Prose of John Clare. Iondon: Routledge \& Kegan Paul, 1951.

\section{Secondary Sources}

Atkins, Vanessa. "What's Love Got To Do . . ." Rev. of A Natural 
History of Love by Diane Ackerman. Creative Loafing 6 Aug 1994. Bate, walter J. John Keats. London: Clarendon Press, 1979. Blackstone, Bernard. The Consecrated Urn. Longman Press, 1959. Bush, Douglas. John Keats: His Life and Writings. New York: Collier Books, 1966. Chilcott, Tim. A real World and Doubting Mind: A Critical Study of the Poetry of John Clare. West Sussex: Hull University Press, 1985.

Crossan, Greg. A Relish for Eternity: The Process of Divinization in the Poetry of John Clare. Salzburg: Institute of Studies in English Literature, 1976. deMan, Paul, Ed. John Keats: Selected Poetry. New York: New American Library, 1966.

Gittings, Robert. John Keats. Boston: Little, Brown, and Company, 1968.

Johnson, Mark, Ed. Philosophical Perspectives on Metaphor.

Minneapolis: University of Minnesota Press, 1981.

Kauvan, Gerald B. The Other Poetry of Keats. Rutherford: Farleigh Dickinson University Press, 1969.

Kipperman, Mark. "John Keats." DNB. Ed. Blake and Nichols. London: 1990, vol. 96 .

Lowe11, Amy - John Keats. New York: Houghton Mifflin Company, 1925. Lucas, John. Modern English Poetry From Hardy to Hughes: A Critical Survey. New Jersey: Barnes and Noble, 1986. Motion, Andrew. "Watchful Heart: the poetics and politics of John 
Clare." Rev. of John Clare in Context edited by Hugh Haughton, Adam Phillips, and Geoffrey Sumerfield. Times Literary Supplement 8 July 1994: 5-6.

Murry, J. Middleton. Keats. New York: Farrar, Strauss, and Cudahy, 1962.

--- Keats and Shakespeare. Oxford: Oxford University Press, 1925.

--. John Clare and Other Studies. Iondon: Peter Nevill, Ltd., 1968.

Purkis, John. The World of the English Romantic Poets: A Visual

Approach. London: Heinemann, 1982.

Richter, Laural S. Rhetorical Constants in the Love Letters of John

Keats to Fanny Brawne. DAI 43 (1982): 454-A. The Catholic University of America.

Robinson, Eric. "John Clare: An Interpretation of Certain Asylum

Letters." The Review of English Studies 13. 50 (1962): 135-146. Rodriguez, Andres. Book of the Heart: The Poetics, Letters, and Life of John Keats. Lindisfarme Press, 1993.

Serdar, Bill. "To Autumn: beyond the passive image." English 507, Portland State University, 14 May 1994.

Storey, Mark, Ed. Clare: The Critical Heritage. Iondon: Routledge and Kegan Paul, 1973.

---. "The Poet Overheard: John Clare and His Audience." The John Clare Society Journal. July 10, 1991: 5-16.

--- The Letters of John Clare. Oxford: Clarendon Press, 1985.

--- The Poetry of John Clare: A Critical Introduction. New York:

St. Martins Press, 1974. 
Todd, Janet M. "Mary Joyce in the Poetry of John Clare." Mary Wollstonecraft Newsletter, 1 July 1972: 12-18.

Van Ghent, Dorothy. Keats: The Myth of the Hero. New Jersey: Princeton University Press, 1983.

--- "Keats's Myth of the Hero." Shelley-Keats Journal. 1984: 7-25. Walsh, William. Introduction to Keats. Iondon: Metheun, 1981. Watts, Cedric. A Preface to Keats. London: Iongmans Press, 1985. 